\title{
Water-Resistant Latex Coatings: Tuning of Properties by Polymerizable Surfactant, Covalent Crosslinking and Nanostructured ZnO Additive
}

\author{
Jana Machotová ${ }^{1}$, Andréa Kalendová ${ }^{1, *}$, Denisa Steinerová $^{1} \mathbb{D}$, Petra Mácová $^{2} \mathbb{D}$, Stanislav Šlang $^{3} \mathbb{D}$, \\ Jaromír Šn̆upárek ${ }^{1}$ and Jan Vajdák ${ }^{4}$ (D)
}

1 Institute of Chemistry and Technology of Macromolecular Materials, Faculty of Chemical Technology, University of Pardubice, Studentská 573, 53210 Pardubice, Czech Republic; jana.machotova@upce.cz (J.M.); steinerovadenisa@gmail.com (D.S.); jaromir.snuparek@upce.cz (J.Š.)

2 Institute of Theoretical and Applied Mechanics of the Czech Academy of Sciences, Prosecká 809/76, 19000 Prague, Czech Republic; macova@itam.cas.cz

3 Center of Materials and Nanotechnologies, Faculty of Chemical Technology, University of Pardubice, Studentská 573, 53210 Pardubice, Czech Republic; stanislav.slang@upce.cz

4 Centre of Polymer Systems, Tomas Bata University in Zlín, Třída Tomáše Bati 5678, 76001 Zlín, Czech Republic; jvajdak@utb.cz

* Correspondence: andrea.kalendova@upce.cz; Tel.: +420-466-037-272

\section{check for}

updates

Citation: Machotová, J.; Kalendová, A.; Steinerová, D.; Mácová, P.; Šlang,

S.; Šňupárek, J.; Vajdák, J.

Water-Resistant Latex Coatings:

Tuning of Properties by

Polymerizable Surfactant, Covalent Crosslinking and Nanostructured ZnO Additive. Coatings 2021, 11, 347. https://doi.org/10.3390/ coatings11030347

Academic Editor: Joseph L. Keddie

Received: 1 March 2021

Accepted: 15 March 2021

Published: 18 March 2021

Publisher's Note: MDPI stays neutral with regard to jurisdictional claims in published maps and institutional affiliations.

Copyright: (c) 2021 by the authors. Licensee MDPI, Basel, Switzerland This article is an open access article distributed under the terms and conditions of the Creative Commons Attribution (CC BY) license (https:// creativecommons.org/licenses/by/ $4.0 /)$.

\begin{abstract}
This paper deals with the development of acrylic latexes providing high-performance water-resistant coatings. For this purpose, mutual effects of anionic surfactant type (ordinary and polymerizable), covalent intra- and/or interparticle crosslinking (introduced by allyl methacrylate copolymerization and keto-hydrazide reaction, respectively) and ionic crosslinking (provided by nanostructured $\mathrm{ZnO}$ additive) were investigated. The latexes were prepared by the standard emulsion polymerization of methyl methacrylate, butyl acrylate and methacrylic acid as the main monomers. The addition of surface-untreated powdered nanostructured $\mathrm{ZnO}$ was performed during latex synthesis, resulting in stable latexes comprising dispersed nanosized additive in the content of ca $0.9-1.0 \mathrm{wt}$.\% (based on solids). The coating performance with emphasis on water resistance was evaluated. It was determined that the application of the polymerizable surfactant improved coating adhesion and water-resistance, but it wasn't able to ensure high water-resistance of coatings. Highly water-resistant coatings were obtained provided that covalent intra- and interparticle crosslinking together with ionic crosslinking were employed in the coating composition, forming densely crosslinked latex films. Moreover, coatings comprising nanostructured $\mathrm{ZnO}$ additive displayed a significant antibacterial activity and improved solvent resistance.
\end{abstract}

Keywords: acrylic latex; crosslinking; keto-hydrazide reaction; polymerizable surfactant; ZnO nanoparticles; water resistance; water whitening; antibacterial activity

\section{Introduction}

Development of ecological coatings has attracted particular interest in coating and paint industry, where acrylic latex binders are of considerable interest due to their favorable properties, such as low cost, resistance to atmospheric conditions, ease of preparation, modification and pigmentation. However, they have the disadvantage of water sensitivity of coatings, which often limits their practical application in high-performance products. The improvement of water resistance of acrylic latex-based coating films is therefore highly challenging and should be addressed preferably already in the synthesis phase of an acrylic emulsion polymer.

One approach to enhance the properties of latex coatings including the water resistance is the employment of intraparticle and interparticle covalent (chemical) crosslinking 
chemistry in emulsion polymers [1,2]. The intraparticle covalent crosslinking, usually introduced by copolymerizing multifunctional monomers such as divinylbenzene, ethylene glycol dimethacrylate or allyl methacrylate (ALMA), often provides rigid latex particles and results in deteriorated film formation [3]. The interparticle covalent crosslinking refers to a chemical reaction designed to occur between adjacent latex particles in the course of film formation. As reflected by number of publications and patents, there has been particular interest in one-pack acrylic coating compositions curable at room temperature [4-6]. Among these materials, self-crosslinking systems based on keto-hydrazide crosslinking reaction have been shown to be particularly effective [7-9]. Diacetone-acrylamide (DAAM) with adipic acid dihydrazide (ADH) is the most favored combination used in the self-crosslinking latexes [10-12]. The most remarkable feature of the keto-hydrazide crosslinking reaction is fast curing at room temperature, providing minimal consumption of energy during processing and easy applicability in case of recoating substrates.

Apart from the covalent crosslinking, the improved protective properties of latex coatings can be achieved by ionic (physical) interparticle crosslinking which occurs in the interfacial zones between adjacent latex particles, through ionic dipolar interactions [2]. In the case of carboxylated latexes, the ionic crosslinks are generated between carboxylic groups on the surface of latex particles in the presence of salts and oxides of multivalent metals [13-15]. The ionic bonds are believed to have the nature of ion multiplets or even larger clusters formed by associated ionized carboxylic groups and metal counterions $[16,17]$. Among the suitable ionic crosslinking additives, $\mathrm{ZnO}$, typically in the form of water dispersion of small particles, has been reported in the relevant literature as an effective crosslinker of latex-based rubbers and coatings [18,19]. As $\mathrm{ZnO}$ has a limited water solubility, it neutralizes (ionizes) carboxylated latexes in the wet state and cures them upon drying. Recently, nanosized $\mathrm{ZnO}$ has been presented in the connection with ionic crosslinking of latex coatings leading to a pronounced improvement of coating protective properties, such as water and solvent resistance, anticorrosion protection and mechanical resistance [20-22]. Nanostructured $\mathrm{ZnO}$ has also met with considerable enthusiasm in the field of latex coatings due to the introduction of UV-shielding and antibacterial properties [23-25].

Another tool, being recognized to be effective in the improvement of water resistance of latex coatings, is the utilization of polymerizable surfactants in the process of emulsion polymerization [26-29]. In the case of the coating films made of latexes synthesized using conventional surfactants, the surfactant molecules, adsorbed on the surface of latex particles, can desorb easily and migrate through the film forming aggregates, which leads to increased penetration of water [30]. The small and mobile surfactant species may also migrate to the air-film interface affecting gloss of the coating film or to the film-substrate interface deteriorating adhesion [31]. By using the polymerizable surfactants, which become covalently attached to the latex particles, the surfactant desorption and migration problems were avoided or at least minimized [32,33]. Positive effects were obtained both on the latex stability and on the properties of the dried coating films [34-37].

The present paper deals with the preparation and evaluation of acrylic latexes suitable for water-resistant high-performance coating applications. While studying the optimal and highly effective latex composition, we concentrated on mutual effects of various unconventional strategies, namely, (i) the emulsion polymerization performed using a polymerizable surfactant, (ii) employing the covalent interparticle crosslinking based on the keto-hydrazide crosslinking reaction, (iii) introducing the covalent intraparticle crosslinking into latex polymer by copolymerizing ALMA and (iv) introducing the ionic crosslinking by means of a nanostructured $\mathrm{ZnO}$ additive, being incorporated in the course of the polymerization process. The latex coating performance with emphasis on water resistance was evaluated and mutually compared. 


\section{Materials and Methods}

\subsection{Materials}

Latexes were prepared of methyl methacrylate (MMA, CAS: 80-62-6), butyl acrylate (BA, CAS: 141-32-2), methacrylic acid (MAA, CAS: 79-41-4), allyl methacrylate (ALMA, CAS: 96-05-9) and diacetone acrylamide (DAAM, CAS: 2873-97-4). All the monomers were purchased from Sigma-Aldrich (Prague, Czech Republic). Disponil FES 993 (BASF, Prague, Czech Republic) was used as the ordinary anionic surfactant. HITENOL AR-10 was used as the polymerizable anionic surfactant and was kindly supplied by DKS Co. Ltd. (Tokyo, Japan). Table 1 presents the main characteristics of the surfactants used in this work. Ammonium persulfate (CAS: 7727-54-0, Penta, Prague, Czech Republic) was utilized as the initiator of the polymerization reaction. Adipic acid dihydrazide (ADH, CAS: 1071-93-8) was utilized as the covalent crosslinking agent and was purchased from TCI Europe (Zwijndrecht, Belgium). Surface-untreated nanostructured ZnO (NanoGard ${ }^{\circledR}$, CAS: 1314-13-2) having the average particle size in the range of $40-100 \mathrm{~nm}$ was used as the ionic crosslinking additive and was purchased from Alfa Aesar (Kandel, Germany). All the chemicals were utilized as received without any further purification.

Table 1. Main characteristics of the used surfactants.

\begin{tabular}{|c|c|c|c|c|}
\hline Surfactant & Type & $\begin{array}{l}\text { Chemical } \\
\text { Composition }\end{array}$ & $\begin{array}{l}\text { Active Matter } \\
\text { (wt.\%) }\end{array}$ & $\begin{array}{l}\text { Critical Micelle } \\
\text { Concentration } \\
(\mathrm{mg} / \mathrm{L})^{\mathrm{a}}\end{array}$ \\
\hline Disponil FES 993 & Nonpolymerizable & $\begin{array}{c}\text { Sodium salt of } \\
\text { ethoxylated fatty } \\
\text { alcohol } \\
\text { ethersulfate }\end{array}$ & 29.7 & 200 \\
\hline $\begin{array}{c}\text { HITENOL } \\
\text { AR-10 }\end{array}$ & Polymerizable & $\begin{array}{l}\text { Ammonium salt } \\
\text { of ethoxylated } \\
\text { styrenated } \\
\text { propenyl phenol } \\
\text { ethersulfate }\end{array}$ & 99.1 & 250 \\
\hline
\end{tabular}

${ }^{a}$ Data given by the supplier.

\subsection{Preparation and Characterization of Latexes}

Four series of acrylic latexes differing in the covalent crosslinking strategy were synthesized by two-step nonseeded emulsion polymerization comprising a variable content of acrylic monomers (see Table 2). The detailed recipe for emulsion polymerization is presented in Table 3. The proportions of the acrylic monomers forming latex particles were chosen to achieve a calculated $T_{\mathrm{g}}$ (using the Fox equation [38]) of approximately $5{ }^{\circ} \mathrm{C}$, so that film-formation was also kept in the case of the densely crosslinked latex films. Every series contained four latex samples which were synthesized using the same types and proportions of the acrylic monomers; two samples always being prepared with an ordinary (nonpolymerizable) surfactant (samples labelled D) and two samples being synthesized using a polymerizable surfactant (samples labelled $\mathrm{H}$ ) that contains reactive double bonds, which can copolymerize with the acrylic monomers. The amounts of the particular surfactants were designed to maintain the same surface-active matter weight concentration in both types of latex samples. Moreover, one of the D-labelled samples and one of the H-labelled samples were synthesized by a standard synthetic route, while the rest two samples (labelled $\mathrm{D}_{-} \mathrm{ZnO}$ and $\mathrm{H}_{2} \mathrm{ZnO}$ ) comprised nanostructured $\mathrm{ZnO}$ as the multifunctional additive, being incorporated in the course of the polymerization process of the second step polymer. The content of nanostructured $\mathrm{ZnO}$ was $1 \mathrm{wt} . \%$ with respect to the total monomer feeds. The way and experimental procedure of the nano- $\mathrm{ZnO}$ addition were based on our recent experience $[20,21,25]$. We have demonstrated that powdered surface-untreated nanostructured $\mathrm{ZnO}$ can be successfully added into a latex in the course of emulsion polymerization, providing a long-term stable coating binder. 
Table 2. Monomeric compositions of latexes differing in the covalent crosslinking strategy, surfactant type and the application of nanostructured $\mathrm{ZnO}$ additive.

\begin{tabular}{|c|c|c|c|c|}
\hline \multirow{3}{*}{ Sample } & \multirow{2}{*}{\multicolumn{2}{|c|}{$\begin{array}{c}\text { Composition of Monomer Feeds (g) } \\
\text { MMA/BA/MAA/DAAM/ALMA }\end{array}$}} & \multirow{3}{*}{ Surfactant Type } & \multirow{3}{*}{$\begin{array}{l}\text { Nanostructured } \\
\text { ZnO Additive }\end{array}$} \\
\hline & & & & \\
\hline & First Step & Second Step & & \\
\hline \multicolumn{5}{|c|}{ Series 1: No covalent crosslinking } \\
\hline $\mathrm{D}_{1}$ & $18.5 / 30 / 1.5 / 0 / 0$ & $18.5 / 30 / 1.5 / 0 / 0$ & nonpolymerizable & no \\
\hline $\mathrm{H}_{1}$ & $18.5 / 30 / 1.5 / 0 / 0$ & $18.5 / 30 / 1.5 / 0 / 0$ & polymerizable & no \\
\hline $\mathrm{D}_{1} \_\mathrm{ZnO}$ & $18.5 / 30 / 1.5 / 0 / 0$ & $18.5 / 30 / 1.5 / 0 / 0$ & nonpolymerizable & yes \\
\hline $\mathrm{H}_{1 \_\mathrm{ZnO}}$ & $18.5 / 30 / 1.5 / 0 / 0$ & $18.5 / 30 / 1.5 / 0 / 0$ & polymerizable & yes \\
\hline \multicolumn{5}{|c|}{ Series 2: Interparticle covalent crosslinking } \\
\hline $\mathrm{D}_{2}$ & $18.5 / 30 / 1.5 / 0 / 0$ & $16.5 / 29.5 / 1.5 / 2.5$ & Ononpolymerizable & no \\
\hline $\mathrm{H}_{2}$ & $18.5 / 30 / 1.5 / 0 / 0$ & $16.5 / 29.5 / 1.5 / 2.5$ & 0 polymerizable & no \\
\hline $\mathrm{D}_{2} \mathrm{ZnO}$ & $18.5 / 30 / 1.5 / 0 / 0$ & $16.5 / 29.5 / 1.5 / 2.5$ & Ononpolymerizable & yes \\
\hline $\mathrm{H}_{2} \mathrm{ZnO}$ & $18.5 / 30 / 1.5 / 0 / 0$ & $16.5 / 29.5 / 1.5 / 2.5$ & 0 polymerizable & yes \\
\hline \multicolumn{5}{|c|}{ Series 3: Intraparticle covalent crosslinking } \\
\hline $\mathrm{D}_{3}$ & $18 / 30 / 1.5 / 0 / 0.5$ & $18.5 / 30 / 1.5 / 0 / 0$ & nonpolymerizable & no \\
\hline $\mathrm{H}_{3}$ & $18 / 30 / 1.5 / 0 / 0.5$ & $18.5 / 30 / 1.5 / 0 / 0$ & polymerizable & no \\
\hline $\mathrm{D}_{3 \_} \mathrm{ZnO}$ & $18 / 30 / 1.5 / 0 / 0.5$ & $18.5 / 30 / 1.5 / 0 / 0$ & nonpolymerizable & yes \\
\hline $\mathrm{H}_{3 \_} \mathrm{ZnO}$ & $18 / 30 / 1.5 / 0 / 0.5$ & $18.5 / 30 / 1.5 / 0 / 0$ & polymerizable & yes \\
\hline \multicolumn{5}{|c|}{ Series 4: Intra- and interparticle covalent crosslinking } \\
\hline $\mathrm{D}_{4}$ & $18 / 30 / 1.5 / 0 / 0.5$ & $16.5 / 29.5 / 1.5 / 2.5$ & Ononpolymerizable & no \\
\hline $\mathrm{H}_{4}$ & $18 / 30 / 1.5 / 0 / 0.5$ & $16.5 / 29.5 / 1.5 / 2.5$ & 0 polymerizable & no \\
\hline $\mathrm{D}_{4 \_} \mathrm{ZnO}$ & $18 / 30 / 1.5 / 0 / 0.5$ & $16.5 / 29.5 / 1.5 / 2.5$ & Ononpolymerizable & yes \\
\hline $\mathrm{H}_{4 \_} \mathrm{ZnO}$ & $18 / 30 / 1.5 / 0 / 0.5$ & $16.5 / 29.5 / 1.5 / 2.5$ & 0 polymerizable & yes \\
\hline
\end{tabular}

Table 3. Recipe for emulsion polymerization by using different surfactants and nanostructured $\mathrm{ZnO}$ additive.

\begin{tabular}{cccc}
\hline Component & $\begin{array}{c}\text { Reaction Flask } \\
\text { Charge (g) }\end{array}$ & $\begin{array}{c}\text { First Step Monomer } \\
\text { Emulsion (g) }\end{array}$ & $\begin{array}{c}\text { Second Step } \\
\text { Monomer Emulsion } \\
\text { (g) }\end{array}$ \\
\hline Water & 35.0 & 47.5 & 72.5 \\
Disponil FES 993 $^{\text {a }}$ & 0.24 & 3.7 & 3.7 \\
HITENOL AR-10 $^{\mathrm{b}}$ & 0.07 & 1.1 & 1.1 \\
Ammonium Persulfate & 0.2 & 0.2 & 0.2 \\
Monomers & - & 50.0 & 50.0 \\
Nanostructured ZnO $^{\mathrm{c}}$ & - & - & 1.0 \\
\hline
\end{tabular}

a Nonpolymerizable surfactant used for the preparation of the D-labelled latex samples. ${ }^{b}$ Polymerizable surfactant used for the preparation of the H-labelled latex samples. ${ }^{\mathrm{C}}$ Ionic crosslinking additive incorporated in the course of the preparation of the $\mathrm{D}_{-} \mathrm{ZnO}-$ and $\mathrm{H}_{-} \mathrm{ZnO}-$ labelled latex samples.

In the Series 1, no covalent crosslinking was introduced into latex polymers. In the Series 2, the composition of the latex samples was designed to provide covalent interparticle crosslinking based on the keto-hydrazide crosslinking reaction. For this purpose, a constant amount of DAAM ( $5 \mathrm{wt} . \%$ with respect to the second step monomer feeds) was incorporated into the second step polymer to introduce ketone carbonyl groups into latex polymers for the subsequent interfacial covalent crosslinking by the reaction with $\mathrm{ADH}$, added during latex formulation. The Series 3 was represented by latexes employing covalent intraparticle crosslinking, which was achieved by introducing a constant amount of ALMA ( $1 \mathrm{wt} . \%$ with respect to the first step monomer feeds) in the first step polymer. In the Series 4, the latexes were designed to provide both covalent inter- and intraparticle crosslinking by copolymerizing DAAM and ALMA in the same manner as described above. In the case of all series, carboxylic functionalities (in a relatively high content, considering standard acrylic latex coating compositions) were incorporated into the structure of the first and second step polymers by copolymerizing MAA ( $3 \mathrm{wt} . \%$ based on total monomer feeds) for three reasons: (i) stabilization of latex particles, (ii) acid catalysis of the keto-hydrazide 
covalent interparticle self-crosslinking reaction, (iii) enabling the ionic crosslinking via $\mathrm{Zn}^{2+}$ cations.

The latexes were produced in a $500 \mathrm{~mL}$ glass reaction flask under a nitrogen atmosphere at a polymerization temperature of $85^{\circ} \mathrm{C}$. The reaction flask charge (consisting of distilled water, initiator and the respective surfactant, see Table 3) was placed into the reaction flask and heated to the polymerization temperature. The monomer emulsion was consequently dosed into the stirred reaction flask at a dosing rate of about $2.5 \mathrm{~mL} / \mathrm{min}$ in two steps (first polymer synthesis, second polymer synthesis), while a 15 min-long period between the two dosing steps was kept. The polymerization was then completed, during the $2 \mathrm{~h}$ of the hold period.

The synthesis of latexes added with nanostructured $\mathrm{ZnO}$ was conducted modifying the above described procedure. First, a finely dispersed $\mathrm{ZnO}$ aqueous dispersion was prepared by adding nanostructured $\mathrm{ZnO}$ to water that was designed for the preparation of the second step monomer emulsion. To facilitate the fragmentation of aggregates formed by $\mathrm{ZnO}$ primary nanoparticles, a proper dispersion process using a SilentCrusher $\mathrm{M}$ disperser (Heidolph, Schwabach, Germany) at 14,000 rpm was carried out for 20 min followed by $1 \mathrm{~h}$-long ultrasonication. The fine nanostructured $\mathrm{ZnO}$ aqueous dispersion was then gently mixed with the monomers, surfactant and initiator designed for the preparation of the second step monomer emulsion (using a stirrer at low speed for $3 \mathrm{~min}$ ). In the end, the resulting second step monomer emulsion with nanostructured $\mathrm{ZnO}$ was dosed to the reaction flask immediately at a dosing rate of about $2.5 \mathrm{~mL} / \mathrm{min}$.

After the synthesis, the latexes were filtered and the coagulum, consisting of filterable solids and solids deposited on the stirrer and the reaction flask walls, was collected. The solids content, coagulum content and monomer conversion were measured by gravimetric method and were calculated according Equations (1)-(3) [39].

$$
\begin{gathered}
\text { solids content }(\text { wt. } \%)=\frac{m_{3}-m_{2}}{m_{1}} \times 100 \\
\text { coagulum content }(\text { wt. } \%)=\frac{m_{C}}{\frac{\text { solids content } \times m_{L}}{100}+m_{C}} \times 100 \\
\text { monomer conversion }(\text { wt. } \%)=\frac{\frac{\text { solids content } \times m_{T}}{100}-\left(m_{I}+m_{S}+m_{\mathrm{ZnO}}\right)}{m_{M}} \times 100
\end{gathered}
$$

where $m_{1}$ is the certain quantity of a latex sample cast onto a Petri dish; $m_{2}$ is the weight of the Petri dish; $m_{3}$ is the weight of the latex sample and the Petri dish dried to a constant weight at $110^{\circ} \mathrm{C} ; m_{C}$ is the weight of the dried coagulum; $m_{L}$ is the weight of the filtered latex; $m_{T}$ is the total weight of all the materials put in the reaction flask; $m_{I}$ is the weight of the initiator; $m_{S}$ is the weight of the surfactant (active matter); $m_{Z n O}$ is the weight of the nanostructured $\mathrm{ZnO}$; and $m_{M}$ is the weight of the total monomers.

The latex $\mathrm{pH}$ was consequently adjusted to 8.5 with ammonia solution. Finally, an aqueous solution of $\mathrm{ADH}$ consisting of $1.25 \mathrm{~g} \mathrm{ADH}$ and $11.3 \mathrm{~g}$ water was added to the latex samples of Series 2 and 4 with agitation. The prepared latexes were evaluated from the point of view of their minimum film-forming temperature (MFFT) and particle size. The minimum film-forming temperature (MFFT) was determined according to ISO 2115 [40], using the MFFT-60 instrument (Rhopoint Instruments, St Leonards, UK). The average particle sizes of polymer particles in the water phase were obtained from dynamic light scattering (DLS) experiments performed using a Litesizer 500 instrument (Anton Paar, Graz, Austria). All the DLS measurements were conducted at $25^{\circ} \mathrm{C}$.

\subsection{Testing of Latex Stability}

The stability of prepared latexes was evaluated using several testing methods. The heat storage stability testing was carried out by storing latexes for 60 days in an oven with a set temperature of $50{ }^{\circ} \mathrm{C}$. The mechanical stability of latexes was evaluated by centrifuging $10 \mathrm{~mL}$ of latex in a sealed centrifugal tube for $15 \mathrm{~min}$ at a speed of $4000 \mathrm{rpm}$ in a centrifugal 
machine. The freeze-thaw stability testing was carried out by storing $10 \mathrm{~mL}$ of latex in a plastic can at $-5,-10$ and $-18^{\circ} \mathrm{C}$, respectively, for about $17 \mathrm{~h}$ and then allowing to thaw for $48 \mathrm{~h}$ at RT. The stability tests mentioned above were evaluated by observing whether there was no coagulation produced after the particular latex stability test and also, whether the tested latex provided smooth coating films without a significant loss of their gloss (below 10 rel.\%). In that case the latex was considered to display the particular stability. A calcium ion stability test was carried out by dropping a small amount (two to three drops) of the latex to $\mathrm{CaCl}_{2}$ solution of a specific concentration $(1,1.5,2$ and $5 \mathrm{wt}$.\%). If there was no precipitation, the latex was considered to have calcium ion stability at the given $\mathrm{CaCl}_{2}$ concentration.

\subsection{Preparation and Characterization of Free-Standing Films}

The free-standing films were prepared by pouring and drying the latexes in silicone molds. The samples were first air-dried at room temperature (RT, $23 \pm 1^{\circ} \mathrm{C}$ ) for a month and then vacuum-dried at $30{ }^{\circ} \mathrm{C}$ for two weeks. The wet thickness of the free-standing films was approximately $0.7 \mathrm{~mm}$. The free-standing films were used for the investigation of latex polymer structure, namely the chemical composition, the glass transition temperature $\left(T_{\mathrm{g}}\right)$ and the degree of crosslinking. In the case of the films based on the latexes comprising the nanostructured $\mathrm{ZnO}$ additive, the distribution and the actual content of $\mathrm{ZnO}$ based nanoparticles inside the coating films were also determined. In addition, the freestanding films were used for the testing of water absorption and antibacterial activity of the latex films.

The chemical structure of the prepared latex polymers was studied employing a Fourier transform infrared (FT-IR) spectroscopy on a secondary module iZ10 of Nicolet iN10 instrument (Thermo Fisher Scientific, Waltham, MA, USA). The infrared spectra were obtained by attenuated total reflectance (ATR) on a built-in all-reflective diamond crystal in a range from $4000 \mathrm{~cm}^{-1}$ to $525 \mathrm{~cm}^{-1}$ using the resolution of $4 \mathrm{~cm}^{-1}$ (64 scans per spectrum). $T_{\mathrm{g}}$ of dried latex polymers was measured by means of differential scanning calorimetry (DSC) using a Pyris 1 DSC instrument (Perkin-Elmer, Waltham, MA, USA). The measurements were performed under $\mathrm{N}_{2}$ atmosphere at a heating rate of $10^{\circ} \mathrm{C} / \mathrm{min}$ from -50 to $120^{\circ} \mathrm{C}$ and the second heating curve was used for $T_{\mathrm{g}}$ determination.

The degree of crosslinking introduced into latex polymers was evaluated according to gel content and crosslink density. The gel content was determined by the extraction in a Soxhlet extractor with tetrahydrofuran (THF) for $24 \mathrm{~h}$ according to CSN EN ISO 6427 [41]. The crosslink density was evaluated from swelling experiments performed on dry gel polymer samples (around $0.2 \mathrm{~g}$ ) which were immersed in toluene at $50{ }^{\circ} \mathrm{C}$ for one week. A swelling time of one week was chosen on the basis of the test results on several samples, which manifested no significant changes after one week of immersion in toluene. At the end of the immersion period, the sample was removed, rapidly blotted with tissue and transferred to a weighing bottle to obtain the swollen weight of the sample. Equations (4)-(7) [42], employing the theory of Flory and Rehner [43], were used to calculate the average molecular weight between crosslinks $\left(M_{\mathrm{C}}\right)$ and the crosslink density (expressed as moles of crosslinks per $\mathrm{cm}^{3}$ of a polymer network), as given in the following:

$$
\begin{gathered}
M_{c}=\frac{\mathrm{V}_{1} \rho_{p}\left[\phi^{\frac{1}{3}}-\phi / 2\right]}{-\left[\ln (1-\phi)+\phi+\chi \phi^{2}\right]} \\
\phi=\frac{\mathrm{W}_{\mathrm{p}} \rho_{\mathrm{s}}}{\mathrm{W}_{\mathrm{p}} \rho_{\mathrm{s}}+\mathrm{W}_{\mathrm{s}} \rho_{\mathrm{p}}} \\
\chi=0.34+\frac{\mathrm{V}_{1}}{\mathrm{RT}}\left(\delta_{1}-\delta_{2}\right)^{2} \\
\text { Crosslink density }=\rho_{\mathrm{p}} / M_{c}
\end{gathered}
$$


where $V_{1}$ is the molar volume of toluene $\left(106.3 \mathrm{~cm}^{3} / \mathrm{mol}\right) ; \rho_{\mathrm{p}}$ is the density of polymer that was calculated to be $1.103 \mathrm{~g} / \mathrm{cm}^{3}$ for the BA/MMA/MAA (60/37/3 by weight) copolymer from $1.06,1.18$ and $1.015 \mathrm{~g} / \mathrm{cm}^{3}$ for poly(BA), poly(MMA) and poly(MAA), respectively; $\varphi$ is the volume fraction of the gel polymer in the swollen gel; $W_{p}$ and $W_{s}$ are the weight fractions of the gel polymer and solvent (toluene) in the swollen gel, respectively; $\rho_{\mathrm{s}}$ is the density of solvent $\left(0.8669 \mathrm{~g} / \mathrm{cm}^{3}\right)$; $\chi$ is the polymer and solvent interaction parameter; $\delta_{1}$ is the solubility parameter of polymer that was calculated to be $9.135\left(\mathrm{cal} / \mathrm{cm}^{3}\right)^{1 / 2}$ for the BA/MMA/MAA $\left(60 / 37 / 3\right.$ by weight) copolymer from $9.0,9.3$ and $9.8\left(\mathrm{cal} / \mathrm{cm}^{3}\right)^{1 / 2}$ for poly(BA), poly(MMA) and poly(MAA), respectively [44,45]; and $\delta_{2}$ is the solubility parameter of toluene, $8.9\left(\mathrm{cal} / \mathrm{cm}^{3}\right)^{1 / 2}$.

The actual content of the nanostructured $\mathrm{ZnO}$ additive, embedded in the dried latex coating films, was determined by means of an inductively coupled plasma optical emission spectrometry (ICP-OES) using a spectrometer INTEGRA XL 2 (GBC, Dandenong, Australia), equipped with a concentric nebulizer and a glass cyclonic spray chamber (both Glass Expansion, Dangenong, Australia). The $\mathrm{ZnO}$ additive concentration was calculated using the simplified assumption that all the determined zinc in the coating film was only in the form of $\mathrm{ZnO}$.

The distribution of $\mathrm{ZnO}$ additive in the coating film was investigated by scanning electron microscopy (SEM) and micro-Raman spectroscopy 2D mapping. The SEM measurements were performed using a LYRA 3 scanning electron microscope (Tescan, Brno, Czech Republic). Observations were conducted on fractured surfaces at the accelerating voltage of $5 \mathrm{kV}$. Samples were placed on carbon tape and carbon coated with a $20 \mathrm{~nm}$ thick layer. The 2D mapping on coating surfaces was performed using a micro-Raman spectrometer Nicolet DXR3xi (Thermo Fisher Scientific, Waltham, MA, USA) equipped with EMCCD detector. The laser beam $(532 \mathrm{~nm})$ was focused with a $100 \times$ objective (N.A $=0.90$ ) and laser power of $5 \mathrm{~mW}$. Maps were collected over an area of $50 \times 100 \mu \mathrm{m}$ using a $0.5 \mu \mathrm{m}$ step size in a spectral range from 3400 to $50 \mathrm{~cm}^{-1}$. Five exposures for each spectrum were recorded with the exposure time of $0.2 \mathrm{~s}$. The analysis of collected data was done by a multivariate curve resolution.

The water absorption expressed in terms of water uptake by the latex films was tested by immersing specimens of the approximate dimensions $20 \times 20 \times 0.7 \mathrm{~mm}^{3}$ in distilled water at RT for 30 days. The soaked film was consequently removed from the water and the surface of the film was carefully dried by touching the polymer with filter paper. The water absorption $(A)$ was calculated according Equation (8).

$$
A=100\left(w_{t}-w_{0}\right) / w_{0}
$$

where $w_{0}$ is the initial weight of a specimen before distilled water exposure and $w_{t}$ is the weight of the specimen after performing the immersion test.

The antibacterial activity of the coating films of the Series 4 (the samples $\mathrm{D}_{4}, \mathrm{H}_{4}, \mathrm{D}_{4} \mathrm{ZnO}$ and $\mathrm{H}_{4} \mathrm{ZnO}$ ) was evaluated and compared using the modified ISO 22,196 method [46]. Four bacterial strains were used for the antimicrobial tests, namely, Staphylococcus aureus ( $S$. Aureus, CCM 4516), Escherichia coli (E. coli, CCM 4517), Enterococcus faecalis (E. faecalis, CCM 3956) and Klebsiella pneumoniae (K. pneumoniae, CCM 4425). All the microbial strains were provided by the Czech Collection of Microorganisms (CCM, Brno, Czech Republic). The coating films were cut into squares of $25 \times 25 \mathrm{~mm}^{2}$, sterilized by UV radiation and then placed in sterile Petri dishes. This was followed by inoculation of the samples using 0.1 $\mathrm{mL}$ of a particular standardized bacteria suspension, namely S. aureus $\left(6.3 \times 10^{6} \mathrm{cfu} / \mathrm{mL}\right)$, E. coli $\left(7.5 \times 10^{6} \mathrm{cfu} / \mathrm{mL}\right)$, E. faecalis $\left(5.1 \times 10^{6} \mathrm{cfu} / \mathrm{mL}\right)$ and K. pneumoniae $\left(1.8 \times 10^{6}\right.$ $\mathrm{cfu} / \mathrm{mL})$. The samples were covered by polypropylene foil $\left(20 \times 20 \mathrm{~mm}^{2}\right)$ disinfected with $70 \%$ ethanol. Incubation of the inoculated samples was performed at $95 \%$ of relative humidity at $35^{\circ} \mathrm{C}$ for $24 \mathrm{~h}$. The polypropylene foil was then removed, and the coating samples were imprinted on Plate Count Agar (HIMEDIA Laboratories Pvt., Mumbai, India). Each coating sample was imprinted three times on different areas of the Plate Count Agar, and incubated at $35^{\circ} \mathrm{C}$ for $24 \mathrm{~h}$. The results were then read and the increase in the 
number of bacterial colonies was evaluated based on scaling from 0 to 5 , where 0 represents the best antimicrobial effect, with no growth of bacteria colonies. All of these analyses were performed using three different coating samples to ensure reliable antibacterial efficiency results.

\subsection{Preparation and Characterization of Coatings Cast on Glass Substrates}

Liquid latexes were applied onto glass panels using a blade applicator. The thickness of the wet coatings was $120 \mu \mathrm{m}$. No coalescing agents were used. The coatings were air-dried at RT and relative humidity of $45 \pm 5 \%$ for seven days. The coating films were evaluated for their gloss, transparency, solvent resistance, adhesion and water whitening. The dry coating thickness was measured using a three-point instrument (BYK-Gardner, Geretsried, Germany). The gloss of coatings was evaluated by a micro-TRI-gloss $\mu$ instrument (BYK-Gardner, Geretsried, Germany) using a gloss-measuring geometry at $60^{\circ}$. Coatings cast on glass panels coated with black matte paint (RAL 9005) were used for the gloss measurements. The transparency of the coatings was evaluated by light transmission (measuring the transmittance at the wavelength $500 \mathrm{~nm}$ ) using a ColorQuest XE Spectrometer (Hunterlab, Reston, VA, USA). The solvent resistance was tested by methyl ethyl ketone (MEK) rubbing following ASTM D 4752. The adhesion of coatings was evaluated by means of the pull-off test according to ISO 4624 using an Elcometer 510 Automatic Adhesion Tester (Elcometer Instruments, Aalen, Germany). All the above-mentioned experiments were carried out at RT.

The water whitening of coatings was evaluated by measuring the change in transmittance at a fixed wavelength $(500 \mathrm{~nm}$, near the green light, which is most sensitive to the human eye) using a ColorQuest XE Spectrometer (Hunterlab, Reston, VA, USA). The coatings were immersed in distilled water at RT for $24 \mathrm{~h}$, followed by the immediate measurement of the transmittance of the exposed coating film area. The extent of water whitening $(W)$ was calculated according Equation (9).

$$
W=100\left(T_{0}-T_{t}\right) / T_{0}
$$

where $T_{0}$ is the coating sample transmittance before immersion in distilled water and $T_{t}$ is the sample transmittance after immersion in distilled water for $24 \mathrm{~h}$.

\section{Results and Discussion}

\subsection{Characterization of Latexes}

The characteristic properties of the prepared latexes, differing in the covalent crosslinking strategy, surfactant type and nanostructured $\mathrm{ZnO}$ addition, are listed in Table 4. In all the polymerizations, regardless of the type of the used surfactant and polymer composition, stable latexes with low amounts of coagulum $(<1 \mathrm{wt} . \%)$ were obtained. This fact indicates a sufficient latex colloidal stability during the synthesis in the case of using the ordinary or the polymerizable type of surfactant. The addition of nanostructured $\mathrm{ZnO}$, carried out during the process of emulsion polymerization, was also shown not to increase significantly the coagulum content in the respective latexes, suggesting no markedly negative effect of the in situ $\mathrm{ZnO}$ addition on latex stability during the synthesis. 
Table 4. Characteristics of latexes, differing in the covalent crosslinking strategy, surfactant type and the application of nanostructured $\mathrm{ZnO}$ additive.

\begin{tabular}{|c|c|c|c|c|c|}
\hline Sample & $\begin{array}{c}\text { Coagulum } \\
\text { Content } \\
\text { (wt.\%) }\end{array}$ & $\begin{array}{l}\text { Solids } \\
\text { (wt.\%) }\end{array}$ & $\begin{array}{c}\text { Conversion } \\
\text { (wt. \%) }\end{array}$ & $\begin{array}{l}\text { Particle Size } \\
\text { (nm) }\end{array}$ & MFFT $\left({ }^{\circ} \mathrm{C}\right)$ \\
\hline \multicolumn{6}{|c|}{ Series 1: No covalent crosslinking } \\
\hline $\mathrm{D}_{1}$ & $\sim 0^{\mathrm{a}}$ & $38.1 \pm 0.1$ & $95.3 \pm 0.3$ & $123.4 \pm 0.8$ & $<0$ \\
\hline $\mathrm{H}_{1}$ & $\sim 0^{\mathrm{a}}$ & $39.7 \pm 0.1$ & $99.5 \pm 0.3$ & $114.3 \pm 0.9$ & $<0$ \\
\hline $\mathrm{D}_{1 \_\mathrm{ZnO}}$ & $\sim 0^{\mathrm{a}}$ & $37.8 \pm 0.1$ & $94.0 \pm 0.2$ & $118.3 \pm 1.8$ & $3.6 \pm 0.2$ \\
\hline $\mathrm{H}_{1 \_\mathrm{ZnO}}$ & 0.2 & $39.2 \pm 0.1$ & $97.8 \pm 0.2$ & $104.9 \pm 1.5$ & $4.5 \pm 0.1$ \\
\hline \multicolumn{6}{|c|}{ Series 2: Interparticle covalent crosslinking } \\
\hline $\mathrm{D}_{2}$ & 0.4 & $38.3 \pm 0.2$ & $95.9 \pm 0.4$ & $120.4 \pm 1.0$ & $<0$ \\
\hline $\mathrm{H}_{2}$ & $\sim 0^{\mathrm{a}}$ & $39.8 \pm 0.1$ & $99.7 \pm 0.2$ & $112.3 \pm 1.0$ & $<0$ \\
\hline $\mathrm{D}_{2} \mathrm{ZnO}$ & 0.6 & $37.0 \pm 0.2$ & $91.9 \pm 0.4$ & $117.9 \pm 1.6$ & $4.1 \pm 0.1$ \\
\hline $\mathrm{H}_{2} \mathrm{ZnO}$ & $\sim 0^{\mathrm{a}}$ & $39.3 \pm 0.1$ & $97.8 \pm 0.2$ & $100.6 \pm 1.3$ & $4.8 \pm 0.2$ \\
\hline \multicolumn{6}{|c|}{ Series 3: Intraparticle covalent crosslinking } \\
\hline $\mathrm{D}_{3}$ & $\sim 0$ & $38.3 \pm 0.1$ & $95.9 \pm 0.3$ & $123.7 \pm 1.0$ & $0.6 \pm 0.2$ \\
\hline $\mathrm{H}_{3}$ & 0.3 & $39.4 \pm 0.2$ & $98.7 \pm 0.4$ & $114.7 \pm 0.7$ & $<0$ \\
\hline $\mathrm{D}_{3} \mathrm{ZnO}$ & 0.1 & $37.2 \pm 0.2$ & $92.4 \pm 0.5$ & $124.7 \pm 1.1$ & $3.8 \pm 0.2$ \\
\hline $\mathrm{H}_{3 \_} \mathrm{ZnO}$ & 0.8 & $38.8 \pm 0.1$ & $96.6 \pm 0.3$ & $112.7 \pm 1.7$ & $5.3 \pm 0.3$ \\
\hline \multicolumn{6}{|c|}{ Series 4: Intra- and interparticle covalent crosslinking } \\
\hline $\mathrm{D}_{4}$ & 0.2 & $38.6 \pm 0.0$ & $96.7 \pm 0.1$ & $118.3 \pm 1.2$ & $1.0 \pm 0.3$ \\
\hline $\mathrm{H}_{4}$ & $\sim 0^{\mathrm{a}}$ & $39.7 \pm 0.2$ & $99.5 \pm 0.5$ & $105.7 \pm 1.1$ & $<0$ \\
\hline $\mathrm{D}_{4 \_} \mathrm{ZnO}$ & $\sim 0^{\mathrm{a}}$ & $37.6 \pm 0.1$ & $93.4 \pm 0.2$ & $121.1 \pm 1.9$ & $4.8 \pm 0.1$ \\
\hline $\mathrm{H}_{4} \_\mathrm{ZnO}$ & 0.7 & $38.9 \pm 0.1$ & $96.8 \pm 0.2$ & $110.8 \pm 1.2$ & $5.9 \pm 0.2$ \\
\hline
\end{tabular}

When comparing the conversion and particle size for the latexes of the same composition but differing in the type of surfactant, a higher monomer conversion and simultaneously a lower final particle size were achieved in the case of using the polymerizable surfactant. This phenomenon has already been reported in the relevant literature [47-50]. It has been ascribed to the increased number of micelles, leading to a higher polymerization rate and a higher number of smaller polymer particles generated during the polymerization process using the polymerizable surfactant.

In addition, the mutual effects of covalent crosslinking strategy, surfactant type, and addition of nanostructured $\mathrm{ZnO}$ on MFFT of latexes were also investigated (see Table 4). As expected, a perceptible increase in MFFT values appeared in the Series 3 and 4, both employing intraparticle covalent crosslinking via ALMA copolymerization, which is generally regarded to introduce rigidity into latex polymer particles [51]. It was also found that the latexes added with nanostructured $\mathrm{ZnO}$ exhibited increased MFFT values in comparison with the corresponding latexes without the $\mathrm{ZnO}$ additive. This effect may be ascribed to the occurrence of ionic interparticle crosslinking, proceeding in the course of the film-formation via carboxylic acid functional groups of emulsion polymer and dissolved $\mathrm{Zn}^{2+}$ ions. When comparing the MFFT values for the corresponding latexes differing in the surfactant type, no remarkable difference was determined.

\subsection{Stability of Latexes}

From a practical point of view, a favorable coating binder has to exhibit a satisfactory stability under various conditions. For that reason, we also tested the stability of the prepared liquid latexes. We used several methods, simulating risks during storing and application, to evaluate the impact of latex composition, including surfactant type and $\mathrm{ZnO}$ addition on the colloidal stability of latexes. In the case of the heat storage stability and the mechanical stability (see Table 5), all the latexes apart from the sample $\mathrm{D}_{4 \_Z n O}$ were found to be stable. The results of freeze-thaw tests (Table 5) based on the freezing cycle at $-5{ }^{\circ} \mathrm{C}$ indicated no coagulation and no significant change in the coating gloss for all the prepared latexes, whereas the freezing cycles at lower temperatures $(-10$ and $-18^{\circ} \mathrm{C}$ ) were found to destabilize the latex samples polymerized with the ordinary surfac- 
tant and those added with nanostructured $\mathrm{ZnO}$. This fact suggests a thin hydration surface layer around polymer particles of these latexes, which caused interparticle coalescence resulting in coagulation. It was also found that the presence of keto-hydrazide chemistry improved the freeze-thaw stability significantly. (Notice all the samples of the Series 2 which manifested an excellent freeze-thaw stability.) This phenomenon can be explained firstly by thickening of the hydration layer (which remains unfrozen) around the particles due to the surface-bound hydrophilic groups of copolymerized DAAM; secondly by the presence of dissolved ADH that could decrease the freezing point of water.

Table 5. Stability testing results of latexes, differing in the covalent crosslinking strategy, surfactant type and the application of nanostructured $\mathrm{ZnO}$ additive.

\begin{tabular}{|c|c|c|c|c|c|}
\hline \multirow{2}{*}{ Sample } & \multirow{2}{*}{$\begin{array}{l}\text { Heat Storage } \\
\text { Stability }^{\mathbf{a}}\end{array}$} & \multirow{2}{*}{$\begin{array}{c}\text { Mechanical } \\
\text { Stability }^{\mathrm{a}}\end{array}$} & \multicolumn{3}{|c|}{ Freeze-Thaw Stability ${ }^{a}$} \\
\hline & & & $\begin{array}{c}\text { Freezing at } \\
-5^{\circ} \mathrm{C}\end{array}$ & $\begin{array}{c}\text { Freezing at } \\
-10^{\circ} \mathrm{C}\end{array}$ & $\begin{array}{c}\text { Freezing at } \\
-18{ }^{\circ} \mathrm{C}\end{array}$ \\
\hline \multicolumn{6}{|c|}{ Series 1: No covalent crosslinking } \\
\hline $\mathrm{D}_{1}$ & $\sqrt{ }$ & $\sqrt{ }$ & $\sqrt{ }$ & $\sqrt{ }$ & $\sqrt{ }$ \\
\hline $\mathrm{H}_{1}$ & $\sqrt{ }$ & $\sqrt{ }$ & $\sqrt{ }$ & $\sqrt{ }$ & $\sqrt{ }$ \\
\hline $\mathrm{D}_{1 \_\mathrm{ZnO}}$ & $\sqrt{ }$ & $\sqrt{ }$ & $\sqrt{ }$ & - & - \\
\hline $\mathrm{H}_{1 \_\mathrm{ZnO}}$ & $\sqrt{ }$ & $\sqrt{ }$ & $\sqrt{ }$ & $\sqrt{ }$ & - \\
\hline \multicolumn{6}{|c|}{ Series 2: Interparticle covalent crosslinking } \\
\hline $\mathrm{D}_{2}$ & $\sqrt{ }$ & $\sqrt{ }$ & $\sqrt{ }$ & $\sqrt{ }$ & $\sqrt{ }$ \\
\hline $\mathrm{H}_{2}$ & $\sqrt{ }$ & $\sqrt{ }$ & $\sqrt{ }$ & $\sqrt{ }$ & $\sqrt{ }$ \\
\hline $\mathrm{D}_{2} \_\mathrm{ZnO}$ & $\sqrt{ }$ & $\sqrt{ }$ & $\sqrt{ }$ & $\sqrt{ }$ & $\sqrt{ }$ \\
\hline $\mathrm{H}_{2} \_\mathrm{ZnO}$ & $\sqrt{ }$ & $\sqrt{ }$ & $\sqrt{ }$ & $\sqrt{ }$ & $\sqrt{ }$ \\
\hline \multicolumn{6}{|c|}{ Series 3: Intraparticle covalent crosslinking } \\
\hline $\mathrm{D}_{3}$ & $\sqrt{ }$ & $\sqrt{ }$ & $\sqrt{ }$ & - & - \\
\hline $\mathrm{H}_{3}$ & $\sqrt{ }$ & $\sqrt{ }$ & $\sqrt{ }$ & $\sqrt{ }$ & $\sqrt{ }$ \\
\hline $\mathrm{D}_{3 \_} \mathrm{ZnO}$ & $\sqrt{ }$ & $\sqrt{ }$ & $\sqrt{ }$ & - & - \\
\hline $\mathrm{H}_{3} \mathrm{ZnO}_{\mathrm{n}}$ & $\sqrt{ }$ & $\sqrt{ }$ & $\sqrt{ }$ & $\sqrt{ }$ & - \\
\hline \multicolumn{6}{|c|}{ Series 4: Intra- and interparticle covalent crosslinking } \\
\hline $\mathrm{D}_{4}$ & $\sqrt{ }$ & $\sqrt{ }$ & $\sqrt{ }$ & - & - \\
\hline $\mathrm{H}_{4}$ & $\sqrt{ }$ & $\sqrt{ }$ & $\sqrt{ }$ & $\sqrt{ }$ & $\sqrt{ }$ \\
\hline $\mathrm{D}_{4 \_Z n O}$ & - & - & $\sqrt{ }$ & - & - \\
\hline $\mathrm{H}_{4 \_Z n O}$ & $\sqrt{ }$ & $\sqrt{ }$ & $\sqrt{ }$ & $\sqrt{ }$ & $\sqrt{ }$ \\
\hline
\end{tabular}

a Stability results expressed by symbols: " $\sqrt{ }$ " means no visible coagulation and the tested latex also provides coatings with a retained gloss (a decrease in gloss $<10$ rel.\%); " $-"$ means visible coagulation and/or the tested latex provides coatings with a deteriorated gloss (a decrease in gloss $>10$ rel. $\%$ ).

The calcium ion stability test (see Table 6) revealed a higher resistance to the electrolyte in the case of the $\mathrm{ZnO}^{-}$added latexes. This effect was observed in all the series, where the $\mathrm{D}_{1 \_\mathrm{ZnO}}$ and $\mathrm{D}_{3 \_\mathrm{ZnO}}$ samples even exhibited the stability at the highest $\mathrm{CaCl}_{2}$ concentration. It was also shown that there was no significant difference in the electrolyte stability between the D-labelled and H-labelled samples. Increased calcium ion stability in the case of the $\mathrm{ZnO}^{-}$added latexes was in all probability caused by a more negatively charged electric layer on the surface of the latex particles. As $\mathrm{ZnO}$ exhibits a limited water solubility, resulting in dissociated $\mathrm{Zn}^{2+}$ and $\mathrm{OH}^{-}$ions, a certain number of the carboxylic groups on the surface of latex particles was ionized, which increased the negative charge of the electric layer surrounding the latex particles. 
Table 6. Calcium ion stability results of latexes, differing in the covalent crosslinking strategy, surfactant type and nanostructured $\mathrm{ZnO}$ addition.

\begin{tabular}{|c|c|c|c|c|}
\hline \multirow[t]{2}{*}{ Sample } & \multicolumn{4}{|c|}{$\begin{array}{c}\mathrm{Ca}^{2+} \text { Stability } \\
\left.\mathrm{CaCl}_{2} \text { Concentration (wt. } \%\right)^{\mathrm{a}} \text { ) }\end{array}$} \\
\hline & 1.0 & 1.5 & 2.0 & 5.0 \\
\hline \multicolumn{5}{|c|}{ Series 1: No covalent crosslinking } \\
\hline $\mathrm{D}_{1}$ & $\sqrt{ }$ & - & - & - \\
\hline $\mathrm{H}_{1}$ & $\sqrt{ }$ & - & - & - \\
\hline $\mathrm{D}_{1 \_\mathrm{ZnO}}$ & $\sqrt{ }$ & $\sqrt{ }$ & $\sqrt{ }$ & $\sqrt{ }$ \\
\hline $\mathrm{H}_{1 \_\mathrm{ZnO}}$ & $\sqrt{ }$ & $\sqrt{ }$ & $\sqrt{ }$ & - \\
\hline \multicolumn{5}{|c|}{ Series 2: Interparticle covalent crosslinking } \\
\hline $\mathrm{D}_{2}$ & $\sqrt{ }$ & - & - & - \\
\hline $\mathrm{H}_{2}$ & $\sqrt{ }$ & - & - & - \\
\hline $\mathrm{D}_{2 \_} \mathrm{ZnO}$ & $\sqrt{ }$ & $\sqrt{ }$ & $\sqrt{ }$ & - \\
\hline $\mathrm{H}_{2} \_\mathrm{ZnO}$ & $\sqrt{ }$ & $\sqrt{ }$ & $\sqrt{ }$ & - \\
\hline \multicolumn{5}{|c|}{ Series 3: Intraparticle covalent crosslinking } \\
\hline $\mathrm{D}_{3}$ & $\sqrt{ }$ & - & - & - \\
\hline $\mathrm{H}_{3}$ & $\sqrt{ }$ & - & - & - \\
\hline $\mathrm{D}_{3 \_} \mathrm{ZnO}$ & $\sqrt{ }$ & $\sqrt{ }$ & $\sqrt{ }$ & $\sqrt{ }$ \\
\hline $\mathrm{H}_{3 \_} \mathrm{ZnO}$ & $\sqrt{ }$ & $\sqrt{ }$ & $\sqrt{ }$ & - \\
\hline \multicolumn{5}{|c|}{ Series 4: Intra- and interparticle covalent crosslinking } \\
\hline $\mathrm{D}_{4}$ & $\sqrt{ }$ & - & - & - \\
\hline $\mathrm{H}_{4}$ & $\sqrt{ }$ & - & - & - \\
\hline $\mathrm{D}_{4 \_} \_\mathrm{ZnO}$ & $\sqrt{ }$ & $\sqrt{ }$ & $\sqrt{ }$ & - \\
\hline $\mathrm{H}_{4 \_} \mathrm{ZnO}$ & $\sqrt{ }$ & $\sqrt{ }$ & $\sqrt{ }$ & - \\
\hline
\end{tabular}

\subsection{Characterization of Coating Structure}

The chemical structure of the coating materials prepared from latexes, differing in the covalent crosslinking strategy, surfactant type and addition of nanostructured $\mathrm{ZnO}$, was analyzed using FT-IR spectroscopy. Representative absorption spectra of coating materials of the Series 1 (providing no crosslinking) and Series 2 (providing interparticle keto-hydrazide crosslinking) are presented in Figures 1 and 2. It can be seen that there are no significant differences between the corresponding samples varying in the surfactant type. All the spectra display a typical pattern of acrylic polymers with a characteristic strong absorption band of the $\mathrm{C}=\mathrm{O}$ bond at $1728 \mathrm{~cm}^{-1}$ assigned to the carboxylic acid ester group. The characteristic absorption band around $1530-1540 \mathrm{~cm}^{-1}$ appearing in the spectra of all the materials of the Series 2 can be attributed to bending vibration of the $\mathrm{N}-\mathrm{H}$ bonds and proves that DAAM was copolymerized with the acrylic monomers. All the polymers of the Series 2 further manifested a weak absorption band around $1640 \mathrm{~cm}^{-1}$ corresponding in all probability to the $\mathrm{N}=\mathrm{C}$ vibration, which indicates that the keto-hydrazide interparticle selfcrosslinking reaction proceeded in the latex polymers [52]. In addition, a broad absorption band of the $\mathrm{O}-\mathrm{H}$ bond around $3250 \mathrm{~cm}^{-1}$ appeared in all the latex samples, being more significant in the case of the $\mathrm{ZnO}$ addition. This absorption band can be assigned to the protonated carboxylic group (from MAA) and hydrogen bonded water. A higher intensity of this band in the case of the samples comprising the $\mathrm{ZnO}$ additive may be attributed to a low solubility of $\mathrm{ZnO}$ in water leading to dissolved $\mathrm{Zn}(\mathrm{OH})_{2}$, which caused a higher degree of ionization of the carboxylic groups. The ionized carboxylic groups were thus responsible for imparting a higher amount of molecularly bonded (hydroplasticizing) water in latex copolymers $[53,54]$. Moreover, a weak absorption band corresponding to the carboxylate anion $v_{\mathrm{a}}(\mathrm{COO})$ appeared around $1600-1610 \mathrm{~cm}^{-1}$ in the spectra of the $\mathrm{D}_{-} \mathrm{ZnO}-$ and $\mathrm{H}_{-} \mathrm{ZnO}-$ labelled samples, which proves again the presence of carboxylic acid salts and also suggests the existence of ionic crosslinking between the carboxylic groups and dissociated $\mathrm{Zn}^{2+}$ cations. The samples of both series also exhibited a weak absorption band of the sulfate anion $v_{\mathrm{a}}\left(\mathrm{SO}_{4}{ }^{2-}\right)$ around $620 \mathrm{~cm}^{-1}$ which corresponds to the presence of the 
sulfate-based emulsifiers and also to the persulfate initiator producing sulfuric acid as the result of the reaction with water. A higher intensity of this band was manifested in the case of the $\mathrm{D}_{-} \mathrm{ZnO}-$ and $\mathrm{H}_{2} \mathrm{ZnO}-$ labelled samples of both series, which suggests that the original $\mathrm{ZnO}$ nanoparticles were converted into zinc sulfate hydroxide $\left(\mathrm{ZnSO}_{4} \cdot 3 \mathrm{Zn}(\mathrm{OH})_{2}\right)$ to some extent, after being subject to the polymerization conditions, as has been evidenced in our previous work [21]. The chemical conversion of nanostructured $\mathrm{ZnO}$ in the strongly acidic aqueous environment of the polymerization system (caused by sulfuric acid generated from the ammonium persulfate initiator) can be represented by Equation $(10)[21,55]$.

$$
\mathrm{ZnO}+\mathrm{H}_{2} \mathrm{SO}_{4}+2 \mathrm{H}_{2} \mathrm{O}=\mathrm{ZnSO}_{4}+3 \mathrm{Zn}(\mathrm{OH})_{2}
$$

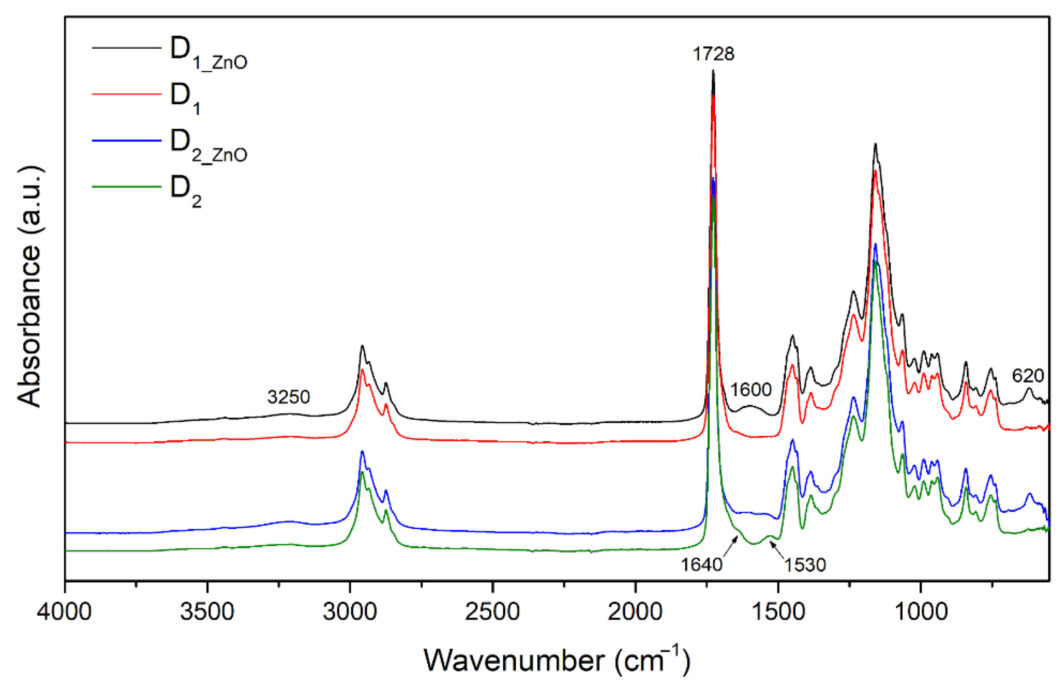

Figure 1. FT-IR spectra of D-labelled latex coatings of Series 1 and Series 2.

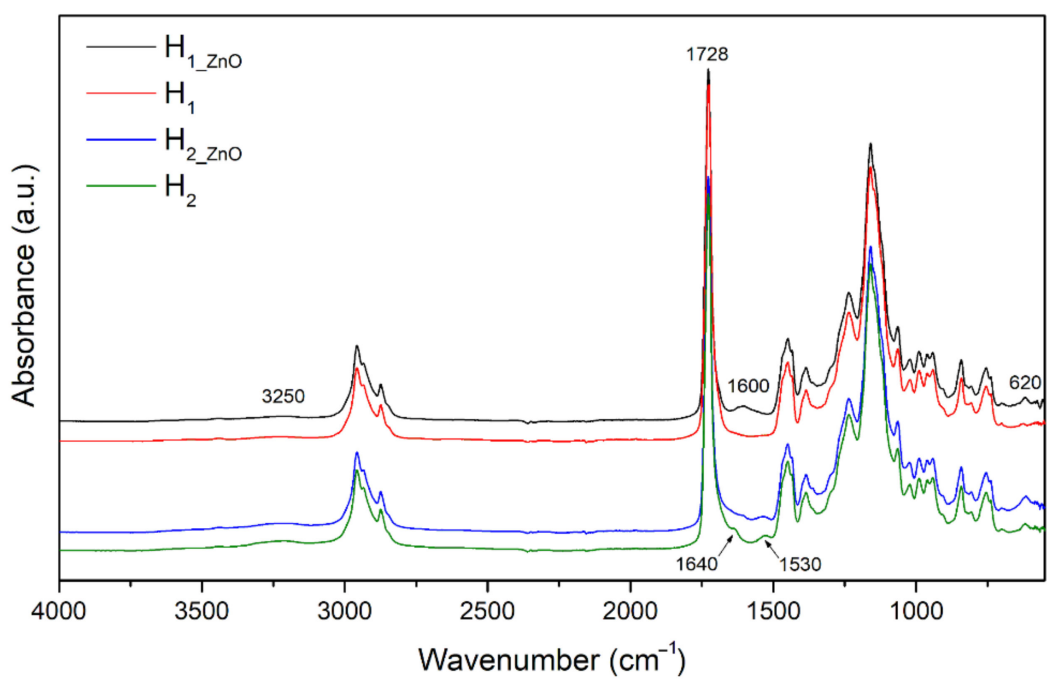

Figure 2. FT-IR spectra of H-labelled latex coatings of Series 1 and Series 2.

The effects of crosslinking strategy, surfactant type and addition of nanostructured $\mathrm{ZnO}$ on the structure of coating materials were also studied from the point of view of polymer $T_{\mathrm{g}}$ (see Table 7). As expected, the presence of the covalent crosslinking was connected with the increase of $T_{\mathrm{g}}$ of latex polymers. This effect was the most pronounced in the Series 4, where both the intra- and interparticle covalent crosslinking strategies were introduced. Focusing on the surfactant type, it can be observed that the H-labelled samples exhibited a higher $T_{\mathrm{g}}$ in contrast to the corresponding D-labelled samples, which may be 
related to the higher molar mass of the latex polymers synthesized with the polymerizable surfactant. This assumption can be deduced from the results of particle size and conversion (see Table 4) showing that the latexes polymerized using the polymerizable surfactant exhibited smaller particles and a higher monomer conversion in comparison with the corresponding latex samples based on the ordinary surfactant. A similar effect has been described for classic emulsion polymerization, where increased concentrations of the ordinary surfactant at a fixed level of initiator were applied. In these cases, the overall molar mass increased because more particles shared the same or even fewer number of radicals (due to the higher polymerization rate) [56]. With regard to the $\mathrm{ZnO}$ addition, the coating samples added with nanostructured $\mathrm{ZnO}$ displayed increased $T_{\mathrm{g}}$ values in comparison with the corresponding blank polymer samples (without $\mathrm{ZnO}$ additive), which indicates again the occurrence of ionic crosslinking.

Table 7. Characteristics of coating materials prepared from latexes, differing in the covalent crosslinking strategy, surfactant type and nanostructured $\mathrm{ZnO}$ addition, in terms of $T_{\mathrm{g}}$, gel content and crosslink density, expressed as the average molecular weight between crosslinks $\left(M_{\mathcal{C}}\right)$, and Zinc content.

\begin{tabular}{|c|c|c|c|c|c|}
\hline Sample & $T_{\mathrm{g}}\left({ }^{\circ} \mathrm{C}\right)$ & $\begin{array}{c}\text { Gel Content } \\
\text { (wt. } \%)\end{array}$ & $M_{\mathrm{c}}(\mathrm{g} / \mathrm{mol})$ & $\begin{array}{l}\text { Zinc Content } \\
\quad(\mathrm{mg} / \mathrm{kg})\end{array}$ & $\begin{array}{c}\text { Actual } \\
\text { Content of } \\
\text { ZnO (wt.\%) }\end{array}$ \\
\hline \multicolumn{6}{|c|}{ Series 1: No covalent crosslinking } \\
\hline $\mathrm{D}_{1}$ & $1.2 \pm 0.2$ & $3.2 \pm 1.8$ & $-{ }^{a}$ & 0 & 0 \\
\hline $\mathrm{H}_{1}$ & $2.4 \pm 0.1$ & $54.0 \pm 0.9$ & $\begin{array}{c}199671 \pm \\
7792\end{array}$ & 0 & 0 \\
\hline $\mathrm{D}_{1 \_\mathrm{ZnO}}$ & $2.6 \pm 0.3$ & $60.0 \pm 1.8$ & $\begin{array}{c}148201 \pm \\
1498\end{array}$ & $7241 \pm 65$ & $0.90 \pm 0.008$ \\
\hline $\mathrm{H}_{1 \_\mathrm{ZnO}}$ & $3.8 \pm 0.3$ & $73.1 \pm 1.5$ & $50726 \pm 2478$ & $7420 \pm 30$ & $0.92 \pm 0.004$ \\
\hline \multicolumn{6}{|c|}{ Series 2: Interparticle covalent crosslinking } \\
\hline $\mathrm{D}_{2}$ & $3.2 \pm 0.3$ & $80.5 \pm 1.6$ & $45612 \pm 5479$ & 0 & 0 \\
\hline $\mathrm{H}_{2}$ & $7.1 \pm 0.2$ & $91.2 \pm 1.1$ & $38254 \pm 5373$ & 0 & 0 \\
\hline $\mathrm{D}_{2} \mathrm{ZnO}$ & $4.1 \pm 0.4$ & $93.0 \pm 2.3$ & $16263 \pm 191$ & $7968 \pm 30$ & $0.99 \pm 0.003$ \\
\hline $\mathrm{H}_{2} \_\mathrm{ZnO}$ & $4.5 \pm 0.2$ & $94.1 \pm 1.6$ & $11884 \pm 105$ & $7309 \pm 10$ & $0.91 \pm 0.001$ \\
\hline \multicolumn{6}{|c|}{ Series 3: Intraparticle covalent crosslinking } \\
\hline $\mathrm{D}_{3}$ & $2.9 \pm 0.4$ & $91.6 \pm 0.7$ & $18273 \pm 150$ & 0 & 0 \\
\hline $\mathrm{H}_{3}$ & $4.1 \pm 0.7$ & $95.8 \pm 1.0$ & $5576 \pm 716$ & 0 & 0 \\
\hline $\mathrm{D}_{3 \_\mathrm{ZnO}}$ & $3.6 \pm 0.5$ & $96.0 \pm 1.7$ & $4050 \pm 121$ & $7967 \pm 50$ & $0.99 \pm 0.005$ \\
\hline $\mathrm{H}_{3 \_} \mathrm{ZnO}$ & $5.3 \pm 0.5$ & $98.6 \pm 2.1$ & $2957 \pm 105$ & $7740 \pm 49$ & $0.96 \pm 0.005$ \\
\hline \multicolumn{6}{|c|}{ Series 4: Intra- and interparticle covalent crosslinking } \\
\hline $\mathrm{D}_{4}$ & $6.3 \pm 0.6$ & $95.6 \pm 2.1$ & $5579 \pm 141$ & 0 & 0 \\
\hline $\mathrm{H}_{4}$ & $7.3 \pm 0.4$ & $97.7 \pm 1.2$ & $3427 \pm 188$ & 0 & 0 \\
\hline $\mathrm{D}_{4 \_\mathrm{ZnO}}$ & $3.6 \pm 0.2$ & $98.9 \pm 1.2$ & $2720 \pm 137$ & $7336 \pm 29$ & $0.92 \pm 0.003$ \\
\hline $\mathrm{H}_{4 \_} \mathrm{ZnO}$ & $6.4 \pm 0.4$ & $99.0 \pm 1.4$ & $1827 \pm 41$ & $7254 \pm 68$ & $0.90 \pm 0.008$ \\
\hline
\end{tabular}

${ }^{a}$ Value was not measured. ${ }^{\mathrm{b}}$ Percentage of $\mathrm{ZnO}$-based nanoparticles in a dried coating film calculated from the inductively coupled plasma optical emission spectrometry (ICP-OES) results using the simplified assumption that all the determined $\mathrm{Zn}$ in the polymer film was only in the form of $\mathrm{ZnO}$.

Additionally, the structure of the coating films in terms of the degree of crosslinking introduced into latex materials was evaluated. The results of gel content, $M_{c}$ (listed in Table 7) and crosslink density (depicted in Figure 3) confirmed that the most densely crosslinked polymer network was formed in the case of latex polymers of the Series 4, employing both inter- and intraparticle covalent crosslinking. A high level of crosslinking was also determined for the samples of the Series 3, which were crosslinked by ALMA copolymerization. However, the polymers of the Series 1 (without any proposed crosslinking strategy) also provided a certain level of crosslinking; minor in the case of the sample $\mathrm{D}_{1}$ and significant in the case of the sample $\mathrm{H}_{1}$. The presence of crosslinked structures in these samples can be explained by intermolecular chain transfer reactions to polymer as a result of BA copolymerization [57]. A comparison of the corresponding samples differing 
in the surfactant type revealed that a higher degree of crosslinking was always detected for the H-labelled polymers, which suggests again a higher molar mass of polymers prepared using the polymerizable surfactant. When comparing the $\mathrm{ZnO}$-added and the blank samples of the same composition, it is evident that additional crosslinks were introduced into latex polymers due to the $\mathrm{ZnO}$ addition. We assume that carboxylic functionalities on the particle surface and also those buried in the particle interior were probably involved in ionic bonding, providing ionic inter- and intraparticle crosslinks. At this stage, it should be mentioned that the ionic intraparticle crosslinks are believed to have proceeded already during the polymer synthesis after dosing the nanostructured $\mathrm{ZnO}$ into the reactor.

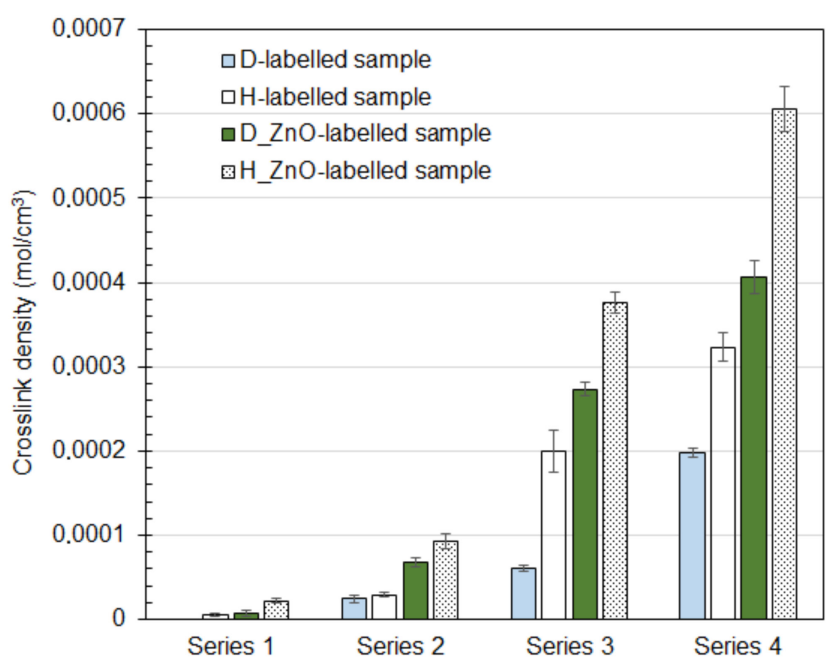

Figure 3. Crosslink density (expressed as moles of crosslinks per $\mathrm{cm}^{3}$ of a polymer network) of the coating films based on latexes, differing in the covalent crosslinking strategy, surfactant type and nanostructured $\mathrm{ZnO}$ addition.

The structure of latex coatings was also examined from the point of view of the actual content and distribution of the nanostructured $\mathrm{ZnO}$ additive in the coating films. The content of the inorganic additive in the respective coating films was determined by the ICP-OES measurements of the zinc concentration (see Table 7). The analysis revealed that the procedure of nanostructured $\mathrm{ZnO}$ incorporation, performed during the process of latex synthesis, provided a comparable portion of the inorganic additive in all the $\mathrm{ZnO}$-based latexes (0.9-1.0 wt.\% in the dried coating films). In addition, the morphology and location of the $\mathrm{ZnO}$ additive inside the representative coating films $\mathrm{D}_{4 \_} \mathrm{ZnO}$ and $\mathrm{H}_{4 \_} \mathrm{ZnO}$ was investigated using SEM (see Figure 4). For better resolution, SEM micrographs of cryofractures of the coating films were taken in both secondary electron (SE) mode (illustrating a topographical view) and backscattered electron (BSE) mode (showing an elementary contrast of the surface). The inorganic additive was shown to be present in the form of distinct nanosized spherical particles (apparently having the predominant chemical nature of $\mathrm{ZnSO}_{4} \cdot 3 \mathrm{Zn}(\mathrm{OH})_{2}$, which were distributed distinctly and regularly inside the polymer matrix, which predetermines the transparent and glossy nature of the resulting coatings. Concurrently, the presence and distribution of the $\mathrm{ZnO}$ additive on the coating surface of the samples $\mathrm{D}_{4 \_} \mathrm{ZnO}$ and $\mathrm{H}_{4 \_} \mathrm{ZnO}$ was monitored using micro-Raman spectroscopy $2 \mathrm{D}$ mapping. Both samples displayed the same character and the representative illustration of the $\mathrm{D}_{4 \_} \mathrm{ZnO}$ coating surface is displayed in Figure 5. Two-dimensional Raman mapping revealed clearly that the surface of latex coatings comprising the $\mathrm{ZnO}$-based additive was homogeneous without micrometer-sized inorganic aggregates. 


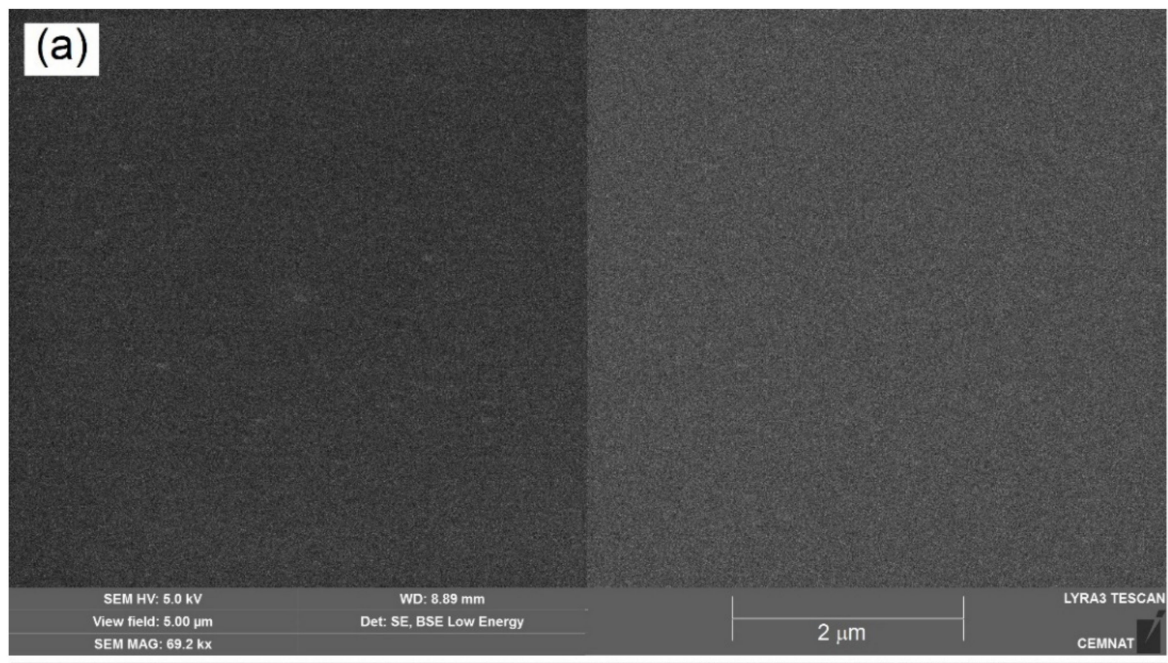

\section{(b)}

\begin{tabular}{|c|c|}
\hline SEM HV: $5.0 \mathrm{kV}$ & WD: $8.37 \mathrm{~mm}$ \\
\hline ew field: $5.00 \mu \mathrm{m}$ & Det: SE, BSE Low Energy \\
\hline
\end{tabular}

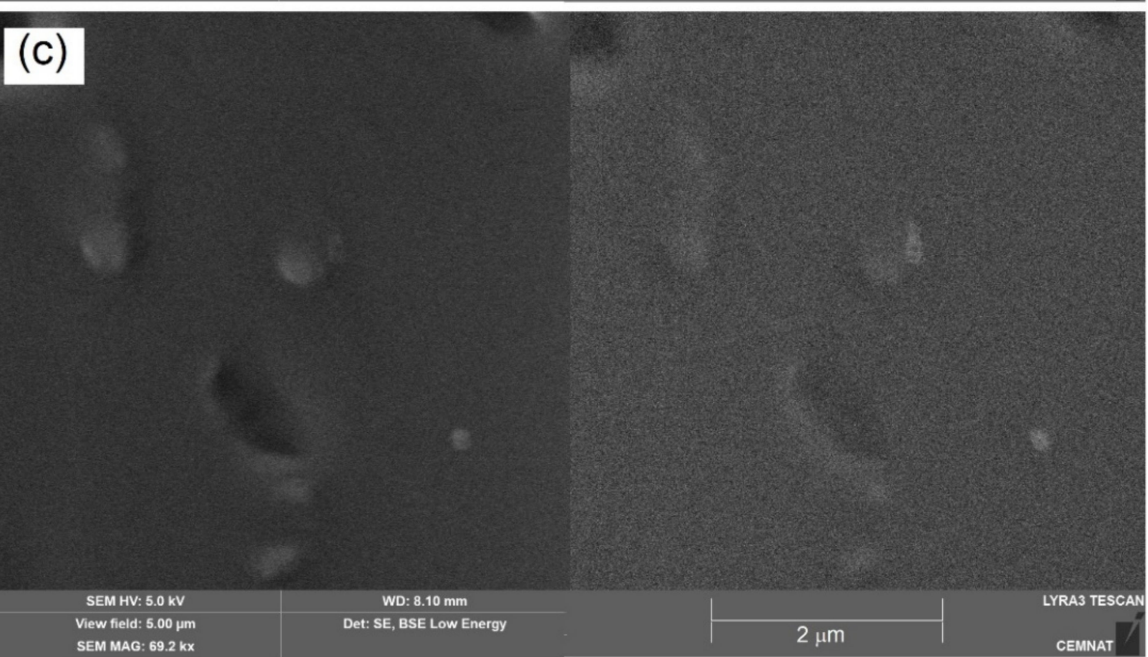

Figure 4. SEM photographs of cryofractures of latex coatings taken in secondary electron (left) and backscattered electron mode (right): (a) blank sample $\mathrm{D}_{4}$; (b) sample $\mathrm{D}_{4 \_} \mathrm{ZnO}$; (c) sample $\mathrm{H}_{4 \_} \mathrm{ZnO}$. The scalebar applies to both SE and BSE images. 


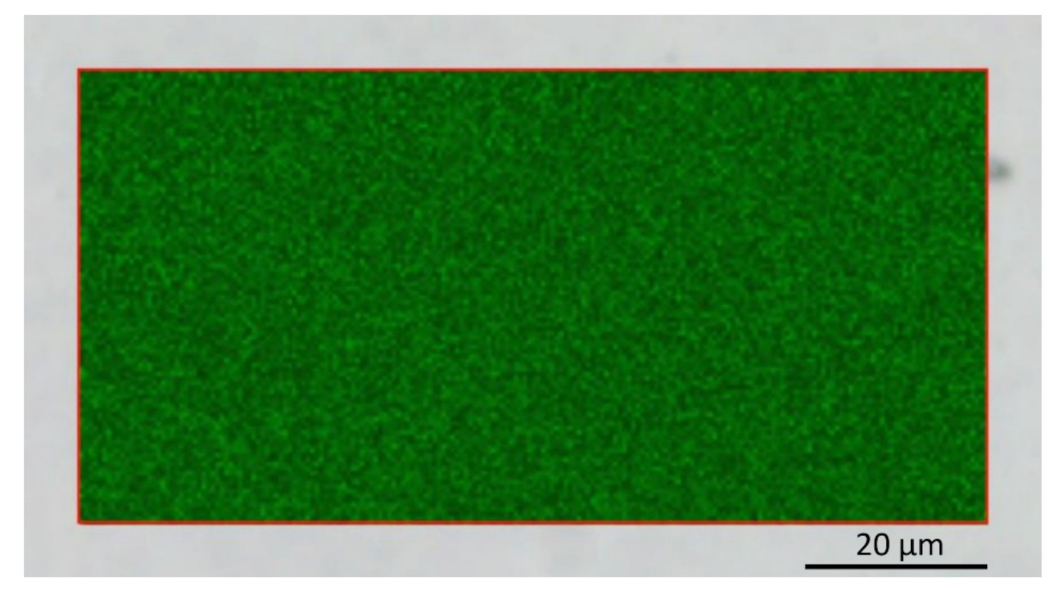

Figure 5. Two-dimensional Raman mapping of the coating surface of the sample $\mathrm{D}_{4 \_Z n O}$. Green color corresponds to the spectrum of the studied latex polymer. A vibration band of sulfate anion at $975 \mathrm{~cm}^{-1}$ was not detected.

\subsection{Coating Properties}

The properties of coatings differing in the covalent crosslinking strategy, surfactant type and nanostructured $\mathrm{ZnO}$ addition are presented in Table 8. The thickness of the dried coatings drawn down on glass substrates was about $50 \mu \mathrm{m}$. All the prepared coatings exhibited a high gloss and transparency without any pronounced difference. We can therefore assume that no significant desorption, migration and aggregation of surfactant molecules and ionic species at the film-air interface occurred (the risk considered especially for the coatings comprising the ordinary surfactant). When comparing MEK resistance of coatings, the results indicated that the solvent resistance wasn't increased markedly by covalent intra- or/and interparticle crosslinking. In contrast, $\mathrm{ZnO}$ additive introducing ionic crosslinks was shown to be a very effective tool for obtaining a high solvent resistance. The coating samples $\mathrm{D}_{2 \_} \mathrm{ZnO}$ and $\mathrm{D}_{4 \_} \mathrm{ZnO}$ even passed the MEK test without failure, which was in all probability caused by the combination of ionic and covalent interparticle crosslinking. The results of the MEK test also revealed that the $\mathrm{D}_{\text {ZnO- }}$ labelled coating samples exhibited a higher MEK resistance in comparison with the corresponding $\mathrm{H}_{-} \mathrm{ZnO}-$ labelled coating samples. This finding may be related to the enhanced molar mass and rigidity of the H-labelled latex polymers (prepared by the polymerizable surfactant). As the ionic crosslinks between the carboxylic groups and zinc ions are supposed to be formed to some extent already during the synthesis of the emulsion polymer, we can assume that more rigid latex particles composed of longer polymer chains linked to each other by ionic bonds (intraparticle crosslinks) were formed in the case of the $\mathrm{H}_{-\mathrm{ZnO}}$ - labelled latexes (resembling the covalent intraparticle crosslinking by ALMA copolymerization). As the result, a porous film structure was apparently formed due to the deteriorated particle deformation and suppressed polymer chain interdiffusion, allowing the solvent molecules to penetrate more easily inside the coating. This effect can be observed more distinctly in the case of a poor MEK resistance for coatings of the Series 3, composed of ALMA-crosslinked latex particles. 
Table 8. Properties of coatings cast on glass substrates.

\begin{tabular}{|c|c|c|c|c|}
\hline Sample & Thickness $(\mu \mathrm{m})$ & Gloss $60^{\circ}(\mathrm{GU})$ & $\begin{array}{c}\text { Transparency } \\
\text { (\%) }{ }^{1}\end{array}$ & $\begin{array}{c}\text { MEK } \\
\text { Resistance } \\
\text { (Number of } \\
\text { Strikes) }\end{array}$ \\
\hline \multicolumn{5}{|c|}{ Series 1: No covalent crosslinking } \\
\hline $\mathrm{D}_{1}$ & $58.4 \pm 8.1$ & $80.5 \pm 0.2$ & $90.1 \pm 0.3$ & $10.3 \pm 0.6$ \\
\hline $\mathrm{H}_{1}$ & $63.2 \pm 7.3$ & $85.1 \pm 0.1$ & $90.2 \pm 0.3$ & $12.3 \pm 0.6$ \\
\hline $\mathrm{D}_{1 \_\mathrm{ZnO}}$ & $61.5 \pm 6.2$ & $85.5 \pm 0.1$ & $89.6 \pm 0.4$ & $210.4 \pm 19.2$ \\
\hline $\mathrm{H}_{1 \_\mathrm{ZnO}}$ & $48.8 \pm 5.4$ & $85.2 \pm 0.2$ & $90.0 \pm 0.3$ & $133.2 \pm 15.1$ \\
\hline \multicolumn{5}{|c|}{ Series 2: Interparticle covalent crosslinking } \\
\hline $\mathrm{D}_{2}$ & $51.8 \pm 7.8$ & $85.0 \pm 0.3$ & $91.0 \pm 0.2$ & $11.8 \pm 1.5$ \\
\hline $\mathrm{H}_{2}$ & $58.6 \pm 6.3$ & $85.2 \pm 0.1$ & $90.2 \pm 0.4$ & $18.7 \pm 0.6$ \\
\hline $\mathrm{D}_{2} \mathrm{ZnO}$ & $55.2 \pm 6.7$ & $86.0 \pm 0.1$ & $89.9 \pm 0.2$ & above $300^{2}$ \\
\hline $\mathrm{H}_{2} \mathrm{ZnO}$ & $60.5 \pm 7.0$ & $85.4 \pm 0.3$ & $90.7 \pm 0.3$ & $213.7 \pm 18.2$ \\
\hline \multicolumn{5}{|c|}{ Series 3: Intraparticle covalent crosslinking } \\
\hline $\mathrm{D}_{3}$ & $61.9 \pm 5.5$ & $84.3 \pm 0.2$ & $91.1 \pm 0.3$ & $8.0 \pm 1.0$ \\
\hline $\mathrm{H}_{3}$ & $58.5 \pm 7.3$ & $84.0 \pm 0.1$ & $90.6 \pm 0.4$ & $10.7 \pm 0.6$ \\
\hline $\mathrm{D}_{3 \_} \mathrm{ZnO}$ & $65.0 \pm 6.7$ & $81.5 \pm 0.4$ & $90.5 \pm 0.2$ & $102.3 \pm 2.4$ \\
\hline $\mathrm{H}_{3 \_} \mathrm{ZnO}$ & $53.5 \pm 4.9$ & $84.3 \pm 0.1$ & $90.6 \pm 0.3$ & $23.1 \pm 4.7$ \\
\hline \multicolumn{5}{|c|}{ Series 4: Intra- and interparticle covalent crosslinking } \\
\hline $\mathrm{D}_{4}$ & $57.5 \pm 6.8$ & $85.2 \pm 0.1$ & $91.1 \pm 0.2$ & $29.4 \pm 4.6$ \\
\hline $\mathrm{H}_{4}$ & $48.1 \pm 8.5$ & $85.5 \pm 0.2$ & $90.2 \pm 0.3$ & $24.6 \pm 6.0$ \\
\hline $\mathrm{D}_{4 \_\mathrm{ZnO}}$ & $45.7 \pm 9.7$ & $85.6 \pm 0.1$ & $89.8 \pm 0.3$ & above 300 \\
\hline $\mathrm{H}_{4 \_\mathrm{ZnO}}$ & $56.5 \pm 6.1$ & $84.9 \pm 0.1$ & $90.6 \pm 0.3$ & $236 \pm 14$ \\
\hline
\end{tabular}

${ }^{1}$ Transmittance measured at $500 \mathrm{~nm} .{ }^{2}$ Maximum evaluative value (representing the best property).

In addition, the adhesion of the coatings to a glass substrate was evaluated (see Figure 6). Focusing on the surfactant type, the results confirmed that the use of the polymerizable surfactant provided improved adhesion of coatings, as has been expected. This effect can be attributed to the covalent attachment of surfactant molecules on the surface of latex particles, disabling their desorption and migration at the substrate-film interface. When comparing the coating adhesion in terms of the covalent crosslinking strategy, the best adhesion to the glass substrate was detected for the coatings of the Series 2 (interparticularly crosslinked by the keto-hydrazide reaction). The reason is in all probability related to the presence of the additional polar functionalities incorporated into the molecular structure of the latex coatings by the keto-hydrazide crosslinks which together with the pendant carboxylic groups on polymer backbone provided secondary interactions between the acrylic polymer chains and the glass substrate. This effect was also manifested in the case of coatings of the Series 4 and explains their enhanced adhesion in comparison with the corresponding coatings of the Series 3. The weaker coating adhesion of the Series 4 in contrast to Series 2 can be attributed to the fixation of polymer chains by ALMA crosslinking, which hindered the orientation of polar functionalities towards the film-substrate interface during film-formation. Focusing on the effect of $\mathrm{ZnO}$ addition causing further polymer chain fixation by ionic crosslinks, the coatings added with nanostructured $\mathrm{ZnO}$ were surprisingly found to provide significantly improved adhesion in comparison with the corresponding coating samples without the $\mathrm{ZnO}$ additive. The improvement of coating adhesion can be explained by ionization of the carboxylic groups by dissolved zinc hydroxide, which resulted in stronger secondary interactions and bonding to glass substrate. 


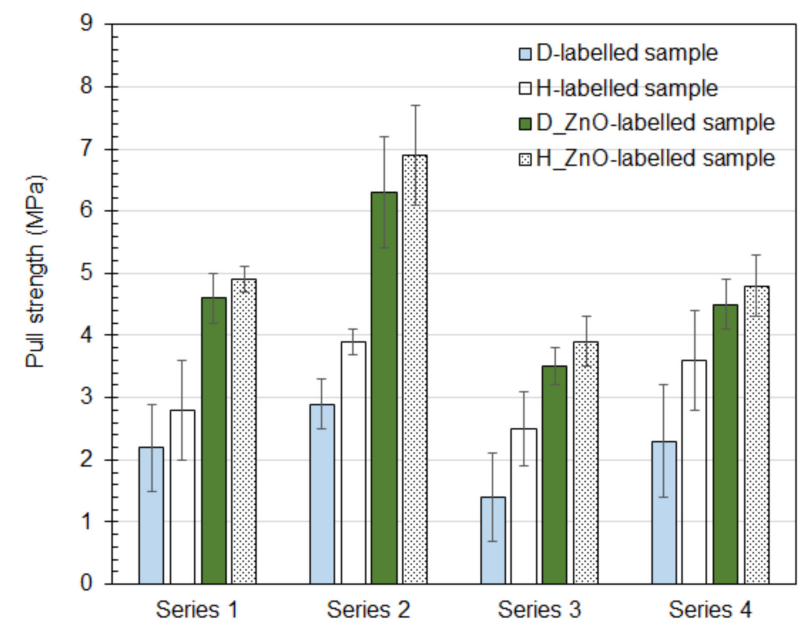

Figure 6. Adhesion (expressed as pull strength) of coatings based on latexes, differing in the covalent crosslinking strategy, surfactant type and addition of nanostructured $\mathrm{ZnO}$.

Water resistance of the latex coating films was evaluated in terms of water absorption (i.e., water uptake) and water whitening (symbolized by a decrease in transmittance). It was evidenced that water resistance of latex coatings can be enhanced markedly by introducing crosslinking $[1-4,21,58]$. The improved water resistance is usually attributed to the enhanced stiffness of crosslinked polymer, which restricts the influx of water and does not allow water domains to grow. In the case of water whitening, it is believed that only water domains exceeding a certain size within the film are responsible for the water whitening effect (light of longer wavelengths becomes more strongly scattered as the domains grow larger) $[54,59]$. The latex films composed of densely crosslinked polymers, after being exposed in water, usually exhibit low water uptake and contain smaller water domains, therefore they are observed less cloudy to the human eye. In contrast, the noncrosslinked or slightly crosslinked latex films generally suffer from high water swelling and pronounced water whitening.

The results of water absorption and water whitening measurements are demonstrated in Figures 7 and 8, respectively. It is obvious that similar trends can be observed for both experiments. Focusing on the covalent crosslinking strategy, the assumptions were fulfilled; the higher the crosslink density (see the results presented in Figure 3), the increased water resistance of the coating films. As expected, the coatings of the Series 1 without any covalent crosslinking were the most water-sensitive, while the most densely crosslinked coatings of the Series 4, combining the intra- and interparticle covalent crosslinking, were shown to be the most water-resistant in terms of both water uptake and water whitening. When comparing the results from the point of view of the surfactant type, the coatings comprising the polymerizable surfactant always provided higher water resistance, which is in all probability related to the smaller interstitial areas (filled only with initiator-based salts) in contrast to the larger interstices (filled also with desorbed surfactant molecules) in the case of the ordinary surfactant-based coatings, leading to decreased osmotic pressure (as the main water penetration driving force) and suppressed influx of water. With regard to the $\mathrm{ZnO}$ addition, it can be stated that the coating films added with nanostructured $\mathrm{ZnO}$ displayed increased water resistance in comparison with the corresponding blank coatings (without $\mathrm{ZnO}$ additive), which corresponds to the increased crosslink density due to the contribution of ionic bonds. However, this claim was contradicted by the results of water absorption of the $\mathrm{H}_{-} \mathrm{ZnO}-$ labelled samples of the Series 1 and 2 that exhibited higher water absorption in comparison with the blank samples of the same composition. The conflict between the results can be explained by the dissolution of a certain portion of nanostructured $\mathrm{ZnO}$, providing a higher amount of ionically charged inorganic components, trapped in interstices between coalesced latex particles. It should be noted at this point that the latexes of the Series 4 , namely the samples $\mathrm{H}_{4}, \mathrm{D}_{4 \_} \mathrm{ZnO}$ and 


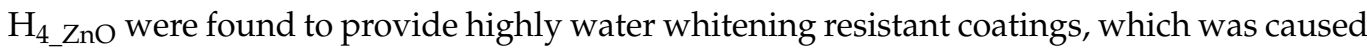
by the occurrence of intra- and intercovalent and ionic crosslinking, resulting in a highly dense polymer network.

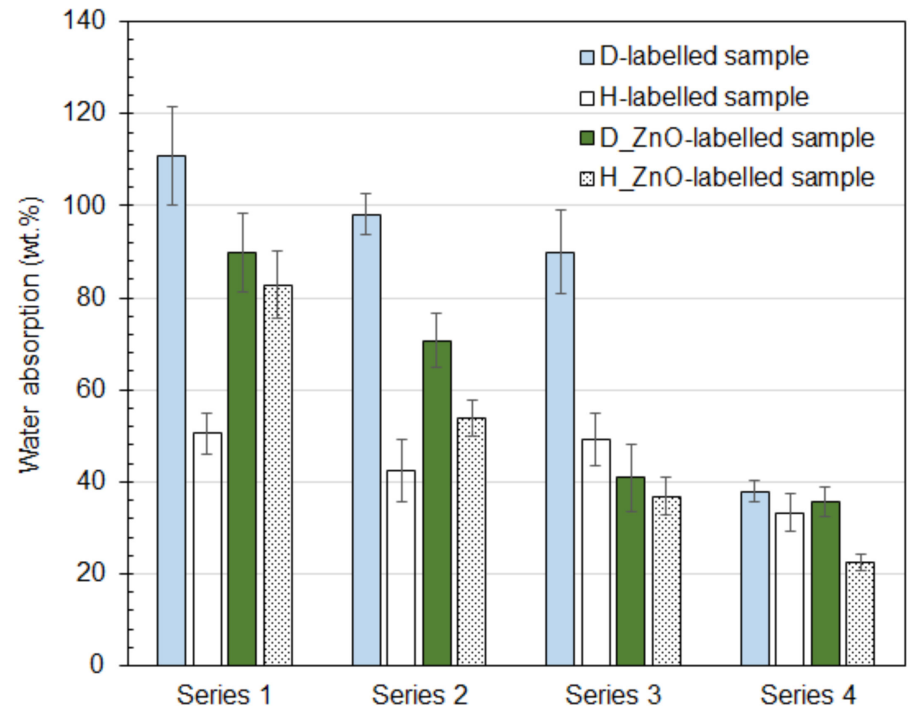

Figure 7. Water absorption into coatings based on latexes, differing in the covalent crosslinking strategy, surfactant type and addition of nanostructured $\mathrm{ZnO}$. The water absorption was measured after 30-day immersion in distilled water at RT.

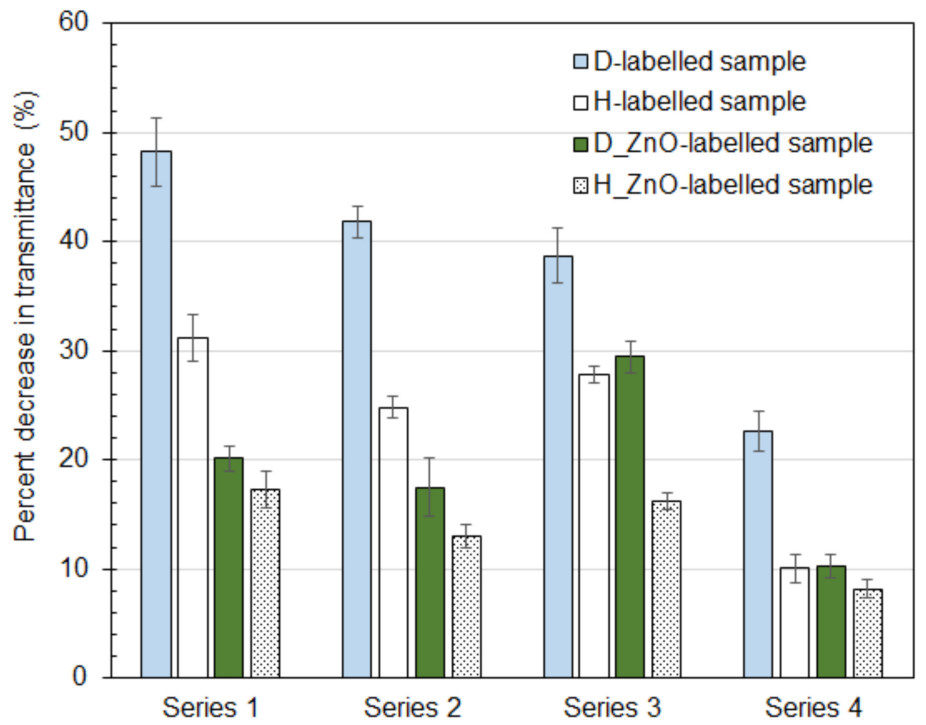

Figure 8. Water whitening of coatings, expressed in terms of transmittance decrease. The water whitening was evaluated after a one-day exposition of coatings cast on glass panels in distilled water. Transmittance values were measured at $500 \mathrm{~nm}$.

Nanostructured $\mathrm{ZnO}$ has been successfully employed as the antibacterial agent in organic coatings [21,60-63]. Its antibacterial effect is still not fully understood, although several mechanisms have been proposed, namely (i) direct contact of nanoparticles with cell walls, resulting in destructing bacterial cell integrity [64], (ii) liberation of antimicrobial $\mathrm{Zn}^{2+}$ ions [65], and (iii) formation of reactive oxygen species including hydrogen peroxide [66,67]. The antibacterial efficiency of the latex coating films of the Series 4, providing the best water resistance, was tested and compared against major food and hospital pathogens, namely S. aureus, E. faecalis (gram-positive bacteria) and E. coli, K. pneumoniae (Gram-negative 
bacteria). Testing revealed (see Table 9) the strong antibacterial activity of all the ZnO-added coatings against $S$. aureus, E. coli and K. pneumoniae and moderate antibacterial efficiency against $E$. faecalis, the latter effect being probably related to the exceptional antioxidative mechanisms in E. faecalis [68]. Considering almost the same content of the $\mathrm{ZnO}$ additive in the respective coatings, it can be supposed that similar results would be also obtained in the case of the Series 1-3. It can be concluded that the addition of nanostructured $\mathrm{ZnO}$ provided a significant antibacterial activity of coatings and, therefore, the nanostructured $\mathrm{ZnO}$ can be considered not only as an effective ionic crosslinking additive but also as an antibacterial agent.

Table 9. Results of antibacterial activity of the coating films of the Series 4 .

\begin{tabular}{ccccc}
\hline \multirow{2}{*}{ Sample } & \multicolumn{4}{c}{ Growth of Bacterial Colonies ${ }^{\text {a }}$} \\
\cline { 2 - 5 } & S. aureus & E. coli & E. faecalis & K. pneumoniae \\
\hline $\mathrm{D}_{4}$ & $5,5,5$ & $5,5,5$ & $4,5,4$ & $5,5,5$ \\
$\mathrm{H}_{4}$ & $5,5,5$ & $5,5,5$ & $5,4,5$ & $5,5,5$ \\
$\mathrm{D}_{4 \_} \mathrm{ZnO}$ & $0,0,0$ & $0,0,0$ & $3,3,3$ & $0,0,0$ \\
$\mathrm{H}_{4 \_} \mathrm{ZnO}$ & $0,0,0$ & $0,0,0$ & $3,3,3$ & $0,0,0$ \\
\hline
\end{tabular}

a The scale for assessing the growth of bacterial colonies: 0-without growth; 1-detectable amount (single colony); 2-detectable amount (combined colony); 3-second imprint, distinguishable colonies, third imprint can be detected; 4-third imprint, distinguishable colonies; 5-overgrown, continuous growth.

\section{Conclusions}

The present study is devoted to the development of latex-based water-resistant acrylic coatings suitable for high-performance applications. To decrease the water sensitivity of coating films, we investigated the combined effects of covalent crosslinking (ALMA-based intraparticle and/or keto-hydrazide-based interparticle), surfactant type (nonpolymerizable and polymerizable), and ionic crosslinking (nanostructured ZnO additive). The addition of nanostructured $\mathrm{ZnO}$, carried out during the process emulsion polymerization, proved to be an effective tool for introducing ionic crosslinks into latex polymers without deteriorating the coating gloss and transparency. Inter- and intraparticle ionic crosslinks were in all probability formed via surface and interior carboxylic functionalities and $\mathrm{Zn}^{2+}$ ions. The results of water resistance testing (focused on water absorption and water whitening) confirmed that the coatings comprising the polymerizable surfactant exhibited improved water resistance in contrast to the ordinary surfactant-based coatings, in all probability due to the presence of smaller interstitial areas (filled only with initiatorbased salts), leading to decreased osmotic pressure and suppressed influx of water. It was further proved that introducing of the covalent crosslinking provided increased waterresistance of coatings, the higher the crosslink density, the more water-resistant coating. In addition, the $\mathrm{ZnO}$ additive was also shown to introduce improved water resistance of coatings, which corresponds to the increased crosslink density due to the contribution of ionic bonds. Highly water-resistant coatings were formed regardless of the surfactant type in case of a concurrent employment of three crosslinking strategies, namely keto-hydrazide crosslinking, ALMA copolymerization and ZnO-based ionic crosslinking. Nevertheless, the application of the polymerizable surfactant was shown to improve significantly coating adhesion, apparently due to the covalent attachment of surfactant molecules to latex particles, disabling their desorption and migration at the substrate-film interface. Moreover, $\mathrm{ZnO}$ addition was shown to provide pronouncedly improved MEK resistance and significant antibacterial activity of the coating films. It can be concluded that environmentally friendly coating binders using nanostructured $\mathrm{ZnO}$ in the role of an ionic and antibacterial additive were developed, providing water- and solvent-resistant hygienic coatings, suitable for the protection of various materials.

Author Contributions: Conceptualization, J.M.; methodology, J.M., A.K., and J.V.; validation, J.M.; investigation, J.M., P.M., and D.S.; writing-original draft preparation, J.M.; writing-review and 
editing, J.Š.; visualization, D.S., P.M., and S.Š.; supervision, J.M.; project administration, A.K. All authors have read and agreed to the published version of the manuscript.

Funding: This research was funded by the Ministry of Education, Youth and Sports of the Czech Republic (project LM2018103) and the Czech Academy of Sciences, Institute of Theoretical and Applied Mechanics (project RVO 68378297). One of us, J.V., acknowledges the support of an internal grant from TBU in Zlín (IGA/CPS/2020/001) financed from funds of specific academic research.

Institutional Review Board Statement: Not applicable.

Informed Consent Statement: Not applicable.

Data Availability Statement: Not applicable.

Acknowledgments: The authors would like to thank Roman Svoboda (University of Pardubice, Faculty of Chemical Technology, Department of Physical Chemistry) for the DSC measurements.

Conflicts of Interest: The authors declare no conflict of interest.

\section{References}

1. Winnik, M.A. Interdiffusion and crosslinking in thermoset latex films. J. Coat. Technol. 2002, 74, 49-63. [CrossRef]

2. Taylor, J.W.; Winnik, M.A. Functional latex and thermoset latex films. Jct Res. 2004, 1, 163-190. [CrossRef]

3. Machotová, J.; Černošková, E.; Honzíček, J.; Šňupárek, J. Water sensitivity of fluorine-containing polyacrylate latex coatings: Effects of crosslinking and ambient drying conditions. Prog. Org. Coat. 2018, 120, 266-273. [CrossRef]

4. Ruckerova, A.; Machotova, J.; Svoboda, R.; Pukova, K.; Bohacik, P.; Valka, R. Ambient temperature self-crosslinking latices using low generation PAMAM dendrimers as inter-particle crosslinking agents. Prog. Org. Coat. 2019, 119, 91-98. [CrossRef]

5. Tillet, G.; Boutevin, B.; Ameduri, B. Chemical reactions of polymer crosslinking and post-crosslinking at room temperature. Prog. Polym. Sci. 2011, 36, 191-217. [CrossRef]

6. Gonzáles, I.; Asua, J.M.; Leiza, J.R. Crosslinking in acetoacetoxy functional waterborne crosslinkable latexes. Macromol. Symp. 2006, 243, 53-62. [CrossRef]

7. Nakayama, Y. Development of novel aqueous coatings which meet the requirements of ecology-conscious society: Novel cross-linking system based on the carbonyl-hydrazide reaction and its applications. Prog. Org. Coat. 2004, 51, 280-299. [CrossRef]

8. Koukiotis, C.G.; Karabela, M.M.; Sideridou, I.D. Mechanical properties of films of latexes based on copolymers BA/MMA/DAAM and BA/MMA/VEOVA-10/DAAM and the corresponding self-crosslinked copolymers using the adipic acid dihydrazide as crosslinking agent. Prog. Org. Coat. 2012, 75, 106-115. [CrossRef]

9. Koukiotis, C.; Sideridou, I.D. Synthesis and characterization of latexes based on copolymers BA/MMA/DAAM and BA/MMA/VEOVA-10/DAAM and the corresponding $1 \mathrm{~K}$ crosslinkable binder using the adipic acid dihydrazide as crosslinking agent. Prog. Org. Coat. 2010, 69, 504-509. [CrossRef]

10. Zhang, X.; Liu, Y.; Huang, H.; Li, Y.; Chen, H. The diacetone acrylamide crosslinking reaction and its control of core-shell polyacrylate lattices at ambient temperature. J. Appl. Polym. Sci. 2012, 123, 1822-1832. [CrossRef]

11. Li, H.; Kan, C.; Du, Y.; Liu, D. Effects of the amount of diacetone acrylamide on the properties of styrene-acrylic copolymer latexes and their films. Polym. Prep. 2002, 43, 413-414.

12. Kessel, N.; Illsley, D.R.; Keddie, J.L. The diacetone acrylamide crosslinking reaction and its influence on the film formation of an acrylic latex. J. Coat. Technol. Res. 2008, 5, 285-297. [CrossRef]

13. Matsuda, H. Ionic crosslinking of carboxyl-terminated liquid rubbers with metal oxides. J. Appl. Polym. Sci. 1979, 24, 811-826. [CrossRef]

14. Zosel, A. Mechanical properties of films from polymer lattices. Polym. Adv. Techol. 2003, 6, 263-269. [CrossRef]

15. Kan, C.S.; Blackson, J.H. Effect of Ionomeric behavior on the viscoelastic properties and morphology of carboxylated latex films. Macromolecules 1996, 29, 6853-6864. [CrossRef]

16. Schuman, T.; Wikström, M.; Rigdahl, M. Dispersion coating with carboxylated and cross-linked styrene-butadiene lattices. 1. Effect of some polymer characteristics on film properties. Prog. Org. Coat. 2004, 51, 220-227. [CrossRef]

17. Richard, J.; Maquet, J. Dynamic micromechanical investigations into particle/particle interfaces in latex films. Polymer 1992, 33, 4164-4173. [CrossRef]

18. Lee, D.I. The effects of latex coalescence and interfacial crosslinking on the mechanical properties of latex films. Polymer 2005, 46, 1287-1293. [CrossRef]

19. Pinprayoon, O.; Saiani, A.; Groves, R.; Saunders, B.R. Particulate ionomer films prepared from dispersions of crosslinked polymer colloids: A structure-property study. J. Colloid Interface Sci. 2009, 336, 73-81. [CrossRef]

20. Machotova, J.; Ruckerova, A.; Bohacik, P.; Pukova, K.; Kalendova, A.; Palarcik, J. High-performance one-pack ambient crosslinking latex binders containing low-generation PAMAM dendrimers and ZnO nanoparticles. J. Coat. Technol. Res. 2018, 15, 1167-1179. [CrossRef] 
21. Machotová, J.; Kalendová, A.; Zlámaná, B.; Šňupárek, J.; Palarčík, J.; Svoboda, R. Waterborne coating binders based on selfcrosslinking acrylic latex with embedded inorganic nanoparticles: A comparison of nanostructured $\mathrm{ZnO}$ and $\mathrm{MgO}$ as crosslink density enhancing agents. Coatings 2020, 10, 339. [CrossRef]

22. Dankova, M.; Kalendova, A.; Machotova, J. Waterborne coatings based on acrylic latex containing nanostructured $\mathrm{ZnO}$ as an active additive. J. Coat. Technol. Res. 2020, 17, 517-529. [CrossRef]

23. Morsi, R.E.; Labena, A.; Khamis, E.A. Core/shell ( $\mathrm{ZnO} /$ polyacrylamide) nanocomposite: In-situ emulsion polymerization, corrosion inhibition, anti-microbial and anti-biofilm characteristics. J. Taiwan Inst. Chem. Eng. 2016, 63, 512-522. [CrossRef]

24. Tang, E.; Cheng, G.; Pang, X.; Ma, X.; Xing, F. Synthesis of nano-ZnO/poly(methyl methacrylate) composite microsphere through emulsion polymerization and its UV-shielding property. Colloid Polym. Sci. 2006, 284, 422-428. [CrossRef]

25. Machotová, J.; Kalendová, A.; Voleská, M.; Steinerová, D.; Pejchalová, M.; Knotek, P.; Zárybnická, L. Waterborne hygienic coatings based on self-crosslinking acrylic latex with embedded inorganic nanoparticles: A comparison of nanostructured $\mathrm{ZnO}$ and $\mathrm{MgO}$ as antibacterial additives. Prog. Org. Coat. 2020, 147, 105704. [CrossRef]

26. Kang, K.; Kan, C.Y.; Du, Y.; Liu, D.S. Synthesis and properties of soap-free poly(methyl methacrylate-ethyl acrylate-methacrylic acid) latex particles prepared by seeded emulsion polymerization. Eur. Polym. J. 2005, 41, 439-445. [CrossRef]

27. Xu, G.; Deng, L.; Wen, X.; Pi, P.; Zheng, D.; Cheng, J.; Yang, Z. Synthesis and characterization of fluorine-containing poly-styreneacrylate latex with core-shell structure using a reactive surfactant. J. Coat. Technol. Res. 2011, 8, 401-407. [CrossRef]

28. Aramendia, E.; Barandiaran, M.J.; Grade, J.; Blease, T.; Asua, J.M. Polymerization of high-solids-content acrylic latexes using a nonionic polymerizable surfactant. J. Polym. Sci. Part A Polym. Chem. 2002, 40, 1552-1559. [CrossRef]

29. Yang, S.F.; Xiong, P.T.; Gong, T.; Lu, D.P.; Guan, R. St-BA copolymer emulsion prepared by using novel cationic maleic dialkyl polymerizable emulsifier. Eur. Polym. J. 2005, 41, 2973-2979. [CrossRef]

30. Filet, A.; Guillot, J.; Hamaide, T.; Guyot, A. Emulsion copolymerization of styrene with a nonionic styrenic polymerizable surfactant. Polym. Adv. Techol. 1995, 6, 465-472. [CrossRef]

31. Chern, C.S.; Chen, Y.C. Semibatch emulsion polymerization of butyl acrylate stabilized by a polymerizable surfactant. Polym. J. 1996, 28, 627-632. [CrossRef]

32. Schoonbrood, H.A.S.; Asua, J.M. Reactive surfactants in heterophase polymerization. 9. Optimum surfmer behaviour in emulsion polymerization. Macromolecules 1997, 30, 6034-6041. [CrossRef]

33. Guyot, A. Advances in reactive surfactants. Adv. Colloid Interface Sci. 2004, 108-109, 3-22. [CrossRef] [PubMed]

34. Hellgren, A.C.; Weissenborn, P.; Holmberg, K. Surfactants in water-borne paints. Prog. Org. Coat. 1999, 35, 79-87. [CrossRef]

35. Chern, C.S.; Chen, Y.C. Stability of the polymerizable surfactant stabilized latex particles during semibatch emulsion polymerization. Colloid Polym. Sci. 1997, 275, 124-130. [CrossRef]

36. Xiao, X.; Wang, Y. Emulsion polymerization of fluorinated acrylate in the presence of a polymerizable emulsifier. Colloids Surf. A Physicochem. Eng. Asp. 2009, 348, 151-156. [CrossRef]

37. Wu, Z.; Zhong, C.Z.; Song, Y.; Zhang, Y.Q. Preparation and characterization of novel acrylate emulsiones with ketone-hydrazide crosslinking structure based on application of reactive emulsifier. Adv. Mat. Res. 2013, 833, 335-338. [CrossRef]

38. Fox, T.G.; Flory, P.J. 2nd-Order transition temperatures and related properties of polystyrene. 1. Influence of molecular weight. J. Appl. Phys. 1950, 21, 581-591. [CrossRef]

39. Ling, H.; Junyan, L. Synthesis, modification and characterization of core-shell fluoroacrylate copolymer latexes. J. Fluor. Chem. 2008, 129, 590-597. [CrossRef]

40. Kumthekar, V.; Kolekar, S. Attributes of the latex emulsion processing and its role in morphology and performance in paints. Prog. Org. Coat. 2011, 72, 380-386. [CrossRef]

41. Kan, C.Y.; Liu, D.S.; Kong, X.Z.; Zhu, X.L. Study on the preparation and properties of styrene-butyl acrylate-silicone copolymer lattices. J. Appl. Polym. Sci. 2001, 82, 3194-3200. [CrossRef]

42. Sperling, L.H. Introduction to Physical Polymer Science, 4th ed.; John Wiley \& Sons: Philadelphia, PA, USA, $2005 ;$ pp. 427-473.

43. Flory, P.J.; Rehner, J. Statistical mechanics of cross-linked polymer networks II. Swelling. J. Chem. Phys. 1943, 11, 521-526. [CrossRef]

44. Tobing, S.; Klein, A. Molecular parameters and their relation to the adhesive performance of acrylic pressure-sensitive adhesives. J. Appl. Polym. Sci. 2001, 79, 2230-2244. [CrossRef]

45. Vandenburg, H.J.; Clifford, A.A.; Bartle, K.D.; Carlson, R.E.; Caroll, J.; Newton, I.D. A simple solvent selection method accelerated solvent extraction of additives from polymers. Analyst 1999, 124, 1707-1710. [CrossRef]

46. Habib, S.; Lehocky, M.; Vesela, D.; Humpolíček, P.; Krupa, I.; Popelka, A. Preparation of progressive antibacterial LDPE surface via active biomolecule deposition approach. Polymers 2019, 11, 1704. [CrossRef] [PubMed]

47. Aguirreurreta, Z.; Cal, J.C.; Leiza, J.R. Anionic polymerizable surfactants and stabilizers in emulsion polymerization: A comparative study. Macromol. React. Eng. 2017, 11, 1600033. [CrossRef]

48. Liu, J.; Chew, C.H.; Gan, L.M.; Teo, W.K.; Gan, L.H. Synthesis of monodisperse polystyrene microlatexes by emulsion polymerization using a polymerizable surfactant. Langmuir 1997, 13, 4988-4994. [CrossRef]

49. Mekki, S.; Saïdi-Besbes, S.; Elaïssari, A.; Valour, J.P.; Derdour, A. Novel polymerizable surfactants: Synthesis and application in the emulsion polymerization of styrene. Polym. J. 2010, 42, 401-405. [CrossRef]

50. Urquiola, M.B.; Dimonie, V.L.; Sudol, E.D.; El-Aasser, M.S. Emulsion polymerization of vinyl acetate using a polymerizable surfactant. I. Kinetic studies. J. Appl. Polym. Sci. Part A Polym. Chem. 1992, 30, 2619-2629. [CrossRef] 
51. Matsumoto, A.; Kodama, K.; Aota, H.; Capek, I. Kinetics of emulsion crosslinking polymerization and copolymerization of allyl methacrylate. Eur. Polym. J. 1999, 35, 1509-1517. [CrossRef]

52. Pi, P.; Wang, W.; Wen, X.; Xu, S.; Cheng, J. Synthesis and characterization of low-temperature self-crosslinkable acrylic emulsion for PE film ink. Prog. Org. Coat. 2015, 81, 66-71. [CrossRef]

53. Tsavalas, J.G.; Sundberg, D.C. Hydroplasticization of polymers: Model predictions and application to emulsion polymers Langmuir 2010, 26, 6960-6966. [CrossRef]

54. Jiang, B.; Tsavalas, J.G.; Sundberg, D.C. Water whitening of polymer films: Mechanistic studies and comparison between water and solvent borne films. Prog. Org. Coat. 2017, 105, 56-66. [CrossRef]

55. Leitner, J.; Sedmidubský, D. Preparation, properties and utilization of nanostructured ZnO. Chem. Listy 2017, 110, 406-417.

56. El-Aasser, M.S.; Tang, J.; Wang, X.; Daniels, E.S.; Dimonie, V.; Sudol, E.D. Advances in emulsion polymerization for coatings applications: Latex blends and reactive surfactants. J. Coat. Technol. 2001, 73, 51-63. [CrossRef]

57. Podzimek, S.; Machotova, J.; Snuparek, J.; Vecera, M.; Prokupek, L. Characterization of molecular structure of acrylic copolymers prepared via emulsion polymerization using A4F-MALS technique. J. Appl. Polym. Sci. 2014, 131, 11178-11185. [CrossRef]

58. Tian, Y.; Du, E.; Abdelmola, F.; Qiang, Y.; Carlsson, L.A. Rapid Characterization of water diffusion in polymer specimens using a droplet-based method. Langmuir 2020, 36, 7309-7314. [CrossRef]

59. Liu, Y.; Gajawicz, A.M.; Rodin, V.; Soer, W.; Scheerder, J.; Satgurunathan, G.; McDonald, P.J.; Keddie, J.L. Explanations for water whitening in secondary dispersion and emulsion polymer films. J. Polym. Sci. Part B Polym. Phys. 2016, 54, 1658-1674. [CrossRef]

60. Schwartz, V.B.; Thétiot, F.; Ritz, S.; Pütz, S.; Choritz, L.; Lappas, A.; Förch, R.; Landfester, K.; Jonas, U. Antibacterial surface coatings from zinc oxide nanoparticles embedded in poly(n-isopropylacrylamide) hydrogel surface layers. Adv. Funct. Mater. 2012, 22, 2376-2386. [CrossRef]

61. Li, J.H.; Hong, R.Y.; Li, M.Y.; Li, H.Z.; Zheng, Y.; Ding, J. Effects of ZnO nanoparticles on the mechanical and antibacterial properties of polyurethane coatings. Prog. Org. Coat. 2009, 64, 504-509. [CrossRef]

62. Seo, J.; Jeon, G.; Jang, E.S.; Khan, S.B.; Han, H. Preparation and properties of poly(propylene carbonate) and nanosized ZnO composite films for packaging applications. J. Appl. Polym. Sci. 2011, 122, 1101-1108. [CrossRef]

63. Chaurasia, V.; Chand, N.; Bajpai, S.K. Water sorption properties and antimicrobial action of zinc oxide nanoparticles-loaded cellulose acetate films. J. Macromol. Sci. Pure Appl. Chem. 2010, 47, 309-317. [CrossRef]

64. Brayner, R.; Ferrari-Iliou, R.; Brivois, N.; Djediat, S.; Benedetti, M.F.; Fievet, F. Toxicological impact studies based on Escherichia coli bacteria in ultrafine $\mathrm{ZnO}$ nanoparticles colloidal medium. Nano Lett. 2006, 6, 866-870. [CrossRef]

65. Pasquet, J.; Chevalier, Y.; Pelletier, J.; Couval, E.; Bouvier, D.; Bolzinger, M.A. The contribution of zinc ions to the antimicrobial activity of zinc oxide. Colloid Surf. A Phys. Eng. Asp. 2014, 457, 263-274. [CrossRef]

66. Sawai, J.; Shoji, S.; Igarashi, H.; Hashimoto, A.; Kokugan, T.; Shimizu, M.; Kojima, H. Hydrogen peroxide as an antibacterial factor in zinc oxide powder slurry. J. Ferment. Bioeng. 1998, 86, 521-552. [CrossRef]

67. Sirelkhatim, A.; Mahmud, S.; Seeni, A.; Kaus, N.H.M.; Ann, L.C.; Bakhori, S.K.M.; Hasan, H.; Mohamad, D. Review on zinc oxide nanoparticles: Antibacterial activity and toxicity mechanism. Nano Micro Lett. 2015, 7, 219-242. [CrossRef] [PubMed]

68. Szemes, T.; Vlkova, B.; Minarik, G.; Tothova, L.; Drahovska, H.; Turna, J.; Celec, P. On the origin of reactive oxygen species and antioxidative mechanisms in Enterococcus faecalis. Redox Rep. 2010, 15, 202-206. [CrossRef] 